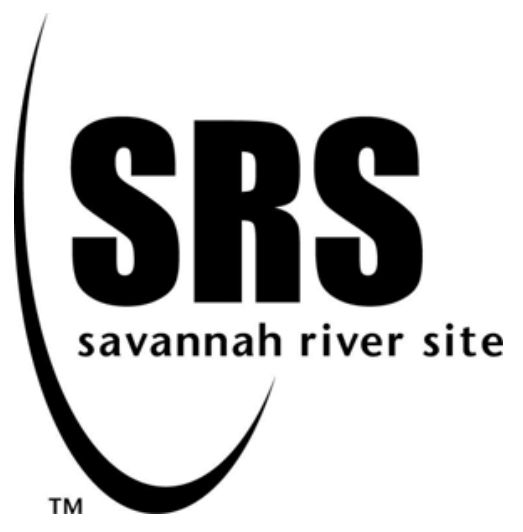

\title{
Fill Stem Manufacturing Changes and Pinch Weld Qualifications
}

\author{
Paul S Korinko \\ David N Maxwell
}

Publication Date: 22 February 2008

\section{Savannah River National Laboratory Washington Savannah River Company Savannah River Site Aiken, South Carolina}

This document was prepared in connection with work done under Contract No. DE-AC0996SR18500 with the U.S. Department of Energy. By acceptance of this document, the publisher and/or recipient acknowledges the U.S. Government's right to retain a nonexclusive, royalty-free license in and to any copyright covering this document, along with the right to reproduce and authorize others to reproduce all or part of the copyrighted material.

WASHINGTON SAVANNAH RIVER COMPANY

The WSRC Team: Washington Savannah River Company LLC • Bechtel Savannah River, Inc. • BNG America Savannah River Corporation • BWXT Savannah River Company • CH2 Savannah River Company 


\title{
Title: Fill Stem Manufacturing Changes and Pinch Weld Qualifications
}

\author{
APPROVALS
}

P.S. Korinko, Author

Date

Materials Compatibility and Welding Technology

D.N Maxwell, Author

Date

Materials Compatibility and Welding Technology

E.A. Clark, Technical Reviewer

Date

Materials Compatibility and Welding Technology

W.L. West

Date

DP Weld Engineer

M.E. Dupont, Acting Manager

Date

Materials Compatibility and Welding Technology 
Table of Contents

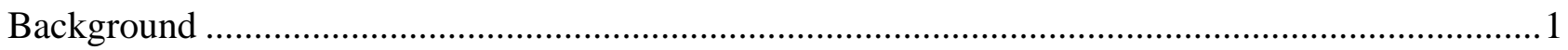

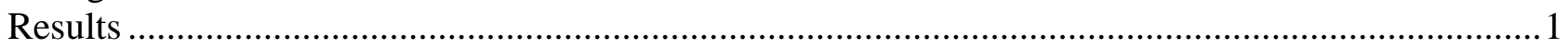

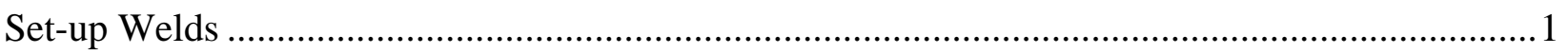

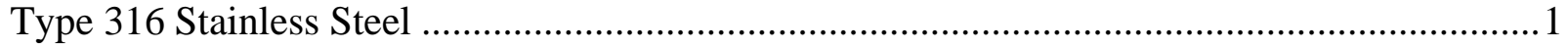

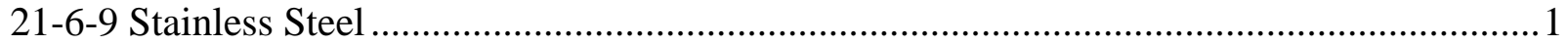

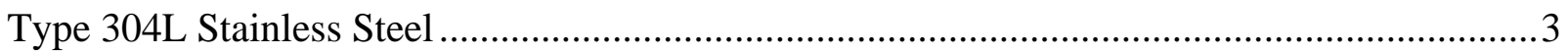

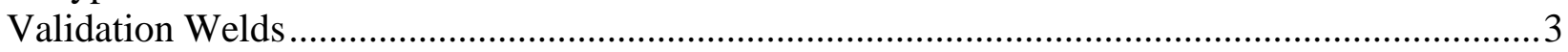

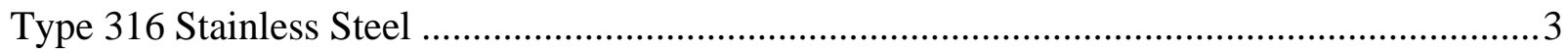

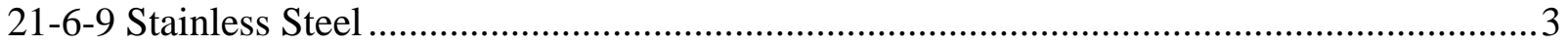

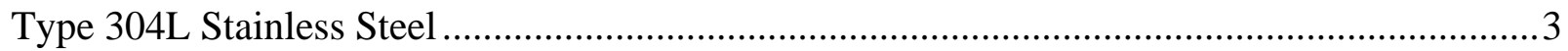

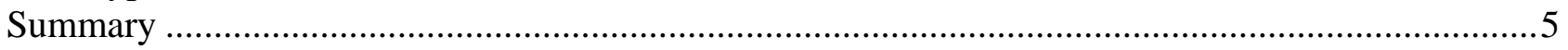

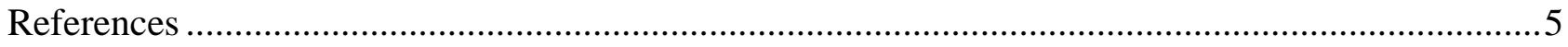

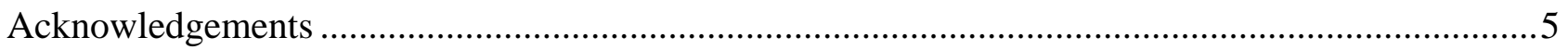

List of Tables

Table 1. Set-up Weld Conditions for Type 316 Stainless Steel Stems, PN PRJ706566-102 ............2

Table 2. Set-up Conditions for 21-6-9 Stainless Steel Stems, PN PRJ706566-102...........................2

Table 3. Set-up Conditions for Type 304L Stainless Steel Stems, PN PRJ706566-102....................2

Table 4. Verification weld data Type 316 Stainless Steel Stems .................................................4

Table 5. Verification weld data 21-6-9 Stainless Steel Stems .................................................... 4

Table 6.Verification weld data Type 304L Stainless Steel Stems ...............................................4

\section{List of Attachments}

Attachment 1. Original document describing machining oil change weld verification....................6

\section{List of Appendices}

Appendix A. Micrographs of Type 316 stem pinch welds used for set-up....................................8

Appendix B. Micrographs of 21-6-9 stem pinch welds used for set-up. ......................................11

Appendix C. Micrographs of Type 304L stem pinch welds used for set-up...................................14

Appendix D. Micrographs of Type 316 stainless steel stems used for weld window verification. ..16 Appendix E. Micrographs of 21-6-9 stainless steel stems used for weld window verification. .......24 Appendix F. Micrographs of Type 304L stainless steel stems used for weld window verification. 30 
This Page Intentionally Left Blank 


\section{Background}

In March of 2007 a document was issued, see attachment I, that defined the test protocol and required welding for the Kansas City Plant to change cutting oils from the recently approved 50:50 oil to an oil with similar characteristics but with different chemistry, additives, and possibly a different vendor due to plans by the current vendor to stop preparing the oils that are used in the KCP 50:50 mix.

The KCP manufactured stems with the existing 50:50 oil blend in late FY07 and SRNL welded the stems and evaluated them in agreement with the test plan. This report provides all the data from these set-up and test welds. Set-up welds were shot and low and high voltages (currents) to ensure the window limits were applicable and then additional welds were made to validate the window. The purpose of this report is to ensure that the agreed upon path forward is still applicable.

\section{Results}

\section{Set-up Welds}

\section{Type 316 Stainless Steel}

The set-up welds were made at voltages consistent with the currents used in the plant for Type 316 stainless steel; samples are identified as B\#\#\#. The target current range was 3300-3700 A. The low current was 3270 and the upper was 3680 which resulted in bond ratings of 3 and 1, respectively. The voltage was increased slightly and another weld was made at 3346 A which resulted in a class 1 bond. Subsequent samples were welded approximately 100 A higher. The weld conditions and response variables are provided in Table 1.

The set-up welds were useful in that the initial conditions did not all meet the weld criteria established for the Type 304L stainless steel stems that were previously studied (Ref. 1). However, a weld window for 316 stainless steel stems machined with 50:50 oil was established. The micrographs showing the weldments are in Appendix A.

\section{1-6-9 Stainless Steel}

Set-up welds for 21-6-9 were shot between 345 and 405 volts (3490 and 4150 A); 21-6-9 stems are designated C\#\#\#. The welds within this voltage (current) range exhibited acceptable cold welds and an unacceptable hot weld, i.e., a weld expulsion (spit). The response variables are listed in Table 2. Even at the low current weld conditions the closure lengths are fairly long. The micrographs of these welds, with the exception of the spit weld are in Appendix B. 
Table 1. Set-up Weld Conditions for Type 316 Stainless Steel Stems, PN PRJ706566-102

\begin{tabular}{|c|c|c|c|c|c|c|c|c|c|c|c|c|c|c|}
\hline ID & $\begin{array}{l}\text { Volt } \\
\text { (V) }\end{array}$ & $\begin{array}{l}\text { Force } \\
\text { (lbs) }\end{array}$ & $\begin{array}{l}\text { Press. } \\
\text { (psi) }\end{array}$ & $\begin{array}{l}\text { Stat. } \\
\text { Res. } \\
(\mathrm{m} \Omega)\end{array}$ & $\begin{array}{l}\text { Dyn. } \\
\text { Res. } \\
(\mathrm{m} \Omega)\end{array}$ & $\begin{array}{l}\text { Weld } \\
\text { Current } \\
\text { (A) }\end{array}$ & $\begin{array}{l}\text { Weld } \\
\text { Energy } \\
(\mathrm{J})\end{array}$ & $\begin{array}{l}\text { Weld } \\
\text { Volt } \\
\text { (V) }\end{array}$ & $\begin{array}{l}\text { Displ. } \\
\text { (in) }\end{array}$ & $\begin{array}{l}\text { Closure } \\
\text { (in) }\end{array}$ & $\begin{array}{l}\text { Extr. } \\
\text { (in) }\end{array}$ & $\begin{array}{l}\text { Comments } \\
\text { Rad. }\end{array}$ & BR & $\begin{array}{l}\text { Comments } \\
\text { Met. }\end{array}$ \\
\hline B061 & 327.8 & 1252 & 108.7 & 0.321 & 0.244 & 3276 & 513.2 & 0.800 & 0.0183 & 0.140 & 0.002 & & 3 & $\begin{array}{l}\text { Almost } \\
\text { Cont. }\end{array}$ \\
\hline B063 & 363.4 & 1253 & 108.8 & 0.296 & 0.228 & 3679 & 605.2 & 0.840 & 0.0221 & 0.172 & 0.014 & & 1 & Nugget \\
\hline B062 & 334.6 & 1247 & 108.3 & 0.314 & 0.245 & 3345 & 535.0 & 0.820 & 0.0190 & 0.155 & 0.008 & & 1 & Nugget \\
\hline
\end{tabular}

Table 2. Set-up Conditions for 21-6-9 Stainless Steel Stems, PN PRJ706566-102

\begin{tabular}{|c|c|c|c|c|c|c|c|c|c|c|c|c|c|c|}
\hline ID & $\begin{array}{l}\text { Volt } \\
\text { (V) }\end{array}$ & $\begin{array}{l}\text { Force } \\
\text { (lbs) }\end{array}$ & $\begin{array}{l}\text { Press. } \\
\text { (psi) }\end{array}$ & $\begin{array}{l}\text { Stat. } \\
\text { Res. } \\
(\mathrm{m} \Omega)\end{array}$ & $\begin{array}{l}\text { Dyn. } \\
\text { Res. } \\
(\mathrm{m} \Omega)\end{array}$ & $\begin{array}{l}\text { Weld } \\
\text { Current } \\
\text { (A) }\end{array}$ & $\begin{array}{l}\text { Weld } \\
\text { Energy } \\
\text { (J) }\end{array}$ & $\begin{array}{l}\text { Weld } \\
\text { Volt } \\
\text { (V) }\end{array}$ & $\begin{array}{l}\text { Displ. } \\
\text { (in) }\end{array}$ & $\begin{array}{l}\text { Closure } \\
\text { (in) }\end{array}$ & $\begin{array}{l}\text { Extr. } \\
\text { (in) }\end{array}$ & $\begin{array}{l}\text { Comments } \\
\text { Rad. }\end{array}$ & BR & $\begin{array}{l}\text { Comments } \\
\text { Met. }\end{array}$ \\
\hline C108 & 345.9 & 1506 & 130.1 & 0.307 & 0.228 & 3490 & 540.0 & 0.796 & 0.0207 & 0.160 & 0.009 & & 2 & Disc line \\
\hline C110 & 381.5 & 1506 & 130.1 & 0.299 & 0.217 & 3895 & 638.1 & 0.845 & 0.0253 & 0.188 & 0.029 & & 1 & Nugget \\
\hline C099 & 404.9 & 1508 & 130.2 & 0.296 & 0.208 & 4153 & 696.0 & 0.866 & 0.0279 & 0.185 & & SPIT & & \\
\hline C098 & 368.6 & 1506 & 130.0 & 0.293 & 0.222 & 3733 & 602.4 & 0.830 & 0.0254 & 0.184 & 0.015 & & 1 & Nugget \\
\hline
\end{tabular}

Table 3. Set-up Conditions for Type 304L Stainless Steel Stems, PN PRJ706566-102

\begin{tabular}{|c|c|c|c|c|c|c|c|c|c|c|c|c|c|c|}
\hline ID & $\begin{array}{l}\text { Volt } \\
\text { (V) }\end{array}$ & $\begin{array}{l}\text { Force } \\
\text { (lbs) }\end{array}$ & $\begin{array}{l}\text { Press. } \\
\text { (psi) }\end{array}$ & $\begin{array}{l}\text { Stat. } \\
\text { Res. } \\
(\mathrm{m} \Omega)\end{array}$ & $\begin{array}{l}\text { Dyn. } \\
\text { Res. } \\
(\mathrm{m} \Omega)\end{array}$ & $\begin{array}{l}\text { Weld } \\
\text { Current } \\
\text { (A) }\end{array}$ & $\begin{array}{l}\text { Weld } \\
\text { Energy } \\
\text { (J) }\end{array}$ & $\begin{array}{l}\text { Weld } \\
\text { Volt } \\
\text { (V) }\end{array}$ & $\begin{array}{l}\text { Displ. } \\
\text { (in) }\end{array}$ & $\begin{array}{l}\text { Closure } \\
\text { (in) }\end{array}$ & $\begin{array}{l}\text { Extr. } \\
\text { (in) }\end{array}$ & $\begin{array}{l}\text { Comments } \\
\text { Rad. }\end{array}$ & BR & $\begin{array}{l}\text { Comments } \\
\text { Met. }\end{array}$ \\
\hline X0122 & 345.3 & 1254 & 108.9 & 0.292 & 0.227 & 3483 & 540.4 & 0.792 & 0.0197 & 0.152 & 0.004 & & 2 & Disc line \\
\hline
\end{tabular}




\section{Type 304L Stainless Steel}

Due to the significant amount of work that was completed during a stem manufacturing and pinch weld task, refs 2 and 3, there was higher confidence that Type 304L stems would be readily prepared. Table 3 contains the weld conditions used and the response variables. The weld window was consistent between the previous work and the current welds. The nominal weld window was 345 to $380 \mathrm{~V}$ (3500 to $3900 \mathrm{~A}$ ). The welds met all the requirements defined in Ref. 1. Appendix C contains typical micrographs.

\section{Validation Welds}

\section{Type 316 Stainless Steel}

Three welds were made at the low heat / current condition and three at the high heat condition. These welds were subjected to visual, dimensional, radiographic, pressure, and metallographic testing. The weld data for the six stems are listed in Table 4. Note that three of the cold welds were made about $10 \mathrm{~V}$ higher than the set-up welds but the closure and extrusion values are about the same. All of the samples passed the $40 \mathrm{ksi}$ pressure test. After determining that these welds exhibited more melting than desired, two additional welds were made at $335 \mathrm{~V}$. These welds were radiographed and metallographically examined, no pressure testing was done. All of the weldments had class 1 and 2 bonds as desired. The micrographs of the weldments are in Appendix D.

\section{1-6-9 Stainless Steel}

As was the case for the 316 stainless steel, the 21-6-9 samples were subjected to the same series of inspections and testing. The data are presented in Table 5. One of the low current samples, C101, exhibited a class 3 bond as rated by a qualified MTF pinch weld inspector. Management review by C. Kestin was not requested and it was decided to not reshoot this condition, since there are four welds at the low value and one that did not pass. The extrusion and bond lengths of the four low current samples are consistent. The micrographs of these six verification welds are shown in Appendix E.

\section{Type 304L Stainless Steel}

Two additional low current and two additional high current samples of type 304L SS stems were welded at the current defined previously. These welds were made to minimize stem usage and the confidence level was high that the weld conditions would be acceptable based on the previous extensive efforts (Refs 2, 3). Uniform weld data was achieved. The weld data are presented in Table 6 and the micrographs in Appendix F. 
Table 4. Verification weld data Type 316 Stainless Steel Stems

\begin{tabular}{|c|c|c|c|c|c|c|c|c|c|c|c|c|c|c|}
\hline ID & $\begin{array}{l}\text { Volt } \\
\text { (V) }\end{array}$ & $\begin{array}{l}\text { Force } \\
\text { (lbs) }\end{array}$ & $\begin{array}{l}\text { Press. } \\
\text { (psi) }\end{array}$ & $\begin{array}{l}\text { Stat. } \\
\text { Res. } \\
(\mathrm{m} \Omega)\end{array}$ & $\begin{array}{l}\text { Dyn. } \\
\text { Res. } \\
(\mathrm{m} \Omega)\end{array}$ & $\begin{array}{l}\text { Weld } \\
\text { Current } \\
\text { (A) }\end{array}$ & $\begin{array}{l}\text { Weld } \\
\text { Energy } \\
\text { (J) }\end{array}$ & $\begin{array}{l}\text { Weld } \\
\text { Volt } \\
\text { (V) }\end{array}$ & $\begin{array}{l}\text { Displ. } \\
\text { (in) }\end{array}$ & $\begin{array}{l}\text { Closure } \\
\text { (in) }\end{array}$ & $\begin{array}{l}\text { Extr. } \\
\text { (in) }\end{array}$ & $\begin{array}{l}\text { Com } \\
\text { Rad. }\end{array}$ & 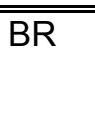 & $\begin{array}{l}\text { Comments } \\
\text { Met. }\end{array}$ \\
\hline B050 & 344.2 & 1254 & 108.8 & 0.307 & 0.236 & 3448 & 549.9 & 0.814 & 0.0194 & 0.154 & 0.007 & & 2 & Disc line with melt \\
\hline B057 & 344.4 & 1252 & 108.6 & 0.306 & 0.237 & 3447 & 548.8 & 0.816 & 0.0194 & 0.155 & 0.008 & Split & 2 & Disc line with melt \\
\hline B058 & 344.4 & 1252 & 108.6 & 0.313 & 0.237 & 3449 & 551.8 & 0.817 & 0.0191 & 0.156 & 0.007 & Split & 2 & Disc line with melt \\
\hline B055 & 363.7 & 1253 & 108.7 & 0.314 & 0.229 & 3668 & 602.8 & 0.840 & 0.0223 & 0.170 & 0.020 & $.030 \mathrm{~B}$ & 1 & Nugget \\
\hline B059 & 363.9 & 1253 & 108.7 & 0.303 & 0.226 & 3672 & 593.8 & 0.831 & 0.0221 & 0.168 & 0.016 & & 1 & Nugget \\
\hline B060 & 364.2 & 1251 & 108.5 & 0.305 & 0.228 & 3672 & 598.6 & 0.838 & 0.0218 & 0.170 & 0.016 & & 1 & Nugget \\
\hline B051 & 330.3 & 1252 & 108.4 & 0.312 & 0.245 & 3315.5 & 522.3 & 0.814 & 0.0851 & 0.145 & 0.004 & & 2 & Disc line with melt \\
\hline B053 & 330.6 & 1257 & 108.8 & 0.308 & 0.243 & 3317.9 & 528.7 & 0.807 & 0.0854 & 0.147 & 0.006 & & 2 & Disc line with melt \\
\hline
\end{tabular}

Table 5. Verification weld data 21-6-9 Stainless Steel Stems

\begin{tabular}{||l|l|l|l|l|l|l|l|l|l|l|l|l|l|l||}
\hline ID & $\begin{array}{l}\text { Volt } \\
(\mathrm{V})\end{array}$ & $\begin{array}{l}\text { Force } \\
(\mathrm{lbs})\end{array}$ & $\begin{array}{l}\text { Press. } \\
(\mathrm{psi})\end{array}$ & $\begin{array}{l}\text { Stat. } \\
\text { Res. } \\
(\mathrm{m} \Omega)\end{array}$ & $\begin{array}{l}\text { Dyn. } \\
\text { Res. } \\
(\mathrm{m} \Omega)\end{array}$ & $\begin{array}{l}\text { Weld } \\
\text { Current } \\
(\mathrm{A})\end{array}$ & $\begin{array}{l}\text { Weld } \\
\text { Energy } \\
(\mathrm{J})\end{array}$ & $\begin{array}{l}\text { Weld } \\
\text { Volt } \\
(\mathrm{V})\end{array}$ & $\begin{array}{l}\text { Displ. } \\
\text { (in) }\end{array}$ & $\begin{array}{l}\text { Closure } \\
\text { (in) }\end{array}$ & $\begin{array}{l}\text { Extr. } \\
\text { (in) }\end{array}$ & $\begin{array}{l}\text { Com. } \\
\text { Rad. }\end{array}$ & $\begin{array}{l}\text { BR } \\
\text { Met. }\end{array}$ & $\begin{array}{l}\text { Comments } \\
\text { Met. }\end{array}$ \\
\hline C103 & 347.1 & 1505 & 129.8 & 0.302 & 0.228 & 3495 & 542.2 & 0.797 & 0.0221 & 0.161 & 0.007 & Split & 2 & Disc line \\
\hline C104 & 347.2 & 1505 & 129.8 & 0.303 & 0.230 & 3491 & 546.2 & 0.804 & 0.0214 & 0.161 & 0.010 & & 2 & Disc line \\
\hline C101 & 347.4 & 1507 & 129.8 & 0.292 & 0.226 & 3497 & 540.5 & 0.790 & 0.0218 & 0.158 & 0.008 & Split & 3 & Almost cont line \\
\hline C105 & 369.9 & 1507 & 129.9 & 0.308 & 0.222 & 3744 & 609.2 & 0.833 & 0.0246 & 0.177 & 0.014 & Split & 1 & Nugget \\
\hline C102 & 370.7 & 1506 & 129.8 & 0.299 & 0.220 & 3758 & 604.8 & 0.828 & 0.0248 & 0.180 & 0.016 & Split & 1 & Nugget \\
\hline C109 & 371.0 & 1507 & 129.9 & 0.305 & 0.221 & 3760 & 607.1 & 0.831 & 0.0250 & 0.180 & 0.016 & 1 & Nugget \\
\hline
\end{tabular}

Table 6.Verification weld data Type 304L Stainless Steel Stems

\begin{tabular}{|c|c|c|c|c|c|c|c|c|c|c|c|c|c|c|}
\hline IID & $\begin{array}{l}\text { Volt } \\
\text { (V) }\end{array}$ & $\begin{array}{l}\text { Force } \\
\text { (lbs) }\end{array}$ & $\begin{array}{l}\text { Press. } \\
\text { (psi) }\end{array}$ & $\begin{array}{l}\text { Stat. } \\
\text { Res. } \\
(\mathrm{m} \Omega)\end{array}$ & $\begin{array}{l}\text { Dyn. } \\
\text { Res. } \\
(\mathrm{m} \Omega)\end{array}$ & $\begin{array}{l}\text { Weld } \\
\text { Current } \\
\text { (A) }\end{array}$ & $\begin{array}{l}\text { Weld } \\
\text { Energy } \\
\text { (J) }\end{array}$ & $\begin{array}{l}\text { Weld } \\
\text { Volt } \\
\text { (V) }\end{array}$ & $\begin{array}{l}\text { Displ. } \\
\text { (in) }\end{array}$ & $\begin{array}{l}\text { Closure } \\
\text { (in) }\end{array}$ & $\begin{array}{l}\text { Extr. } \\
\text { (in) }\end{array}$ & $\begin{array}{l}\text { Com. } \\
\text { Rad. }\end{array}$ & $\overline{P B R}$ & $\begin{array}{l}\text { Comments } \\
\text { Met. }\end{array}$ \\
\hline $\mathrm{X} 0119$ & 345.7 & 1251 & 108.5 & 0.306 & 0.237 & 3467 & 558.2 & 0.821 & 0.0186 & 0.162 & 0.009 & & 2 & line \\
\hline $\mathrm{X} 0116$ & 345.7 & 1243 & 107.9 & 0.330 & 0.235 & 3469 & 546.2 & 0.815 & 0.0188 & 0.154 & 0.005 & Split & 2 & Disc line \\
\hline X0115 & 381.5 & 1251 & 108.5 & 0.318 & 0.219 & 3876 & 639.1 & 0.848 & 0.0215 & 0.180 & 0.017 & Split & 1 & Nugget \\
\hline $\mathrm{X} 0120$ & 381.9 & 1253 & 108.7 & 0.304 & 0.222 & 3870 & 645.1 & 0.858 & 0.0239 & 0.183 & 0.019 & $.033 \mathrm{~B}$ & 1 & Nugget \\
\hline
\end{tabular}




\section{Summary}

A series of welds were made on fill stems of Type 316, 21-6-9, and Type 304L stainless steel machined with the Koch's current machining oil termed 50:50. The weld window was established / verified for the alloys and several stems were welded at the low and high currents for the stems. All but one of the welds passed the inspection criteria.

The weld conditions defined in this task will be used to weld a series of ten stems made with the new machining oil that KCP will be implementing at the beginning calendar year 2008.

\section{References}

1. WSRC-RP-2005-01589, "Pinch Weld Technical Specification for Screening Design of Experiments (DOEx)”, P. Korinko, May 2005.

2. KCP-613-8133, “Nuclear Weapons Complex Screening Experiment to Identify Variables Critical to Stem Closure Welds”, K. Arnold (KCP) \& P. Korinko, May 2006.

3. WSRC-STI-2006-00158, “Optimization Study for Fill Stem Manufacturing and Pinch Weld Processing”, P. Korinko \& K Arnold (KCP), Sept. 2006.

4. WSRC-STI-2006-00158, "Validation Study for Fill Stem Manufacturing and Pinch Weld Processing”, P. Korinko \& K Arnold (KCP), Aug. 2006

\section{Acknowledgements}

The authors would like to acknowledge the support and assistance they received from W. West, DP radiographers, MTF staff for reading test welds, T. Curtis and L. Thacker for metallographic sample preparation, G. Crowe, C. Allen, D. Holliday, G. Sides, and W. Good for pressure testing support. 


\section{Attachment 1. Original document describing machining oil change weld verification}

SRNL-MST-2007-00066

Fill Stem Manufacturing Changes and Pinch Weld Qualifications

To: C. Cadden, B. Meyer, K. Arnold, D. Grote, J. McGrath, W. West, S. Mazurek, J. McCowan, S. West, M. Dupont, D. Maxwell

Based on previous discussions from the Stem Team the following protocol is recommended to ensure that manufacturing changes that are not expected to result in the need for a full qualification in the tritium facility. In order to accomplish this task with the fewest reasonable number of stems, the following plan is tendered:

1. Determine weld conditions on the SRNL prototypic welder for 316 stainless steel fill stems that produce class 1 and 2 bonds. Test stems of the PRJ706566-102 will be used. The stems will be machined with 50/50 cutting oil

A. Preliminary conditions for 316 based on email dated 3-6-07 from B. West

3/16” electrode, 1250 lbs +/- 50 lbs, current from 3300-3700 A for WR weld conditions

Weld in 2 atm of Nitrogen or deuterium

Weld one stem each at $3300 \mathrm{~A}$ and 3500A and 3700A

Proof test at $40 \mathrm{ksi}$

$\mathrm{X}$-ray for closure length, extrusion, and geometry

Transverse metallographic examination

B. Based on these conditions either increase or decrease current (voltage) range for welds, weld a new set to if range is changed.

Weld three 50/50 test stems at the low and high conditions, with current at low and force at high and current at high with force low, to ensure suitable weld parameters

2. Determine weld conditions on the SRNL prototypic welder for 21-6-9 stainless steel fill stems that produce class 1 and 2 bonds.

A. Preliminary conditions for 21-6-9 based on email dated 3-6-07 from B. West

3/16” electrode, 1500 lbs, current from 3750 to 4150 A for WR weld conditions (this simulates $\mathrm{M}$ conditions).

Weld one stem each at $3750 \mathrm{~A}, 3950 \mathrm{~A}$, and 4150A

Weld in 2 atm of Nitrogen or deuterium

Proof test at $60 \mathrm{ksi}$

$\mathrm{X}$-ray for closure length, extrusion, and geometry

Transverse metallographic examination

B. Based on these conditions either increase or decrease current (voltage) range for welds. Weld three 50/50 test stems at the low and high conditions, with current at low and force at high and current at high with force low, to ensure suitable weld parameters 
3. Use current range established during fill stem project for 304L (3500-3900) A.

Based on these conditions weld three 50/50 test stems at the low and high conditions, with current at low and force at high and current at high with force low, to ensure suitable weld parameters

Using these conditions, weld a total of ten stems of each material manufactured using modified, i.e., changed cutting oil, process. Weld four stems at "cold" condition, three at midpoint (nominal) condition, and three at "hot" condition, varying force opposite of current. Use standard suite of non-destructive and destructive tests to ensure acceptable quality.

Upon successful completion of these tasks, issue report(s) detailing the work that was completed and circulate to stakeholders. Include recommendation indicating approval of process for WR components.

The Tritium Facility will weld qualification stems as part of their normal quality assurance program for equipment validation prior to loading reservoirs. A full requalification of the process will not be required.

Test stems needed:

\begin{tabular}{|c|c|c|c|}
\hline Type & Quantity & Cutting Fluid & Purpose \\
\hline $21-6-9$ & 6 & $50 / 50$ & Weld window tuning \\
\hline $21-6-9$ & 6 & $50 / 50$ & Low and high validation \\
\hline 21-6-9 & 12 & New & Process verification (and 2 contingency) \\
\hline 316 & 6 & $50 / 50$ & Weld window tuning \\
\hline 316 & 6 & $50 / 50$ & Low and high validation \\
\hline 316 & 12 & New & Process verification (and 2 contingency) \\
\hline 304L & 6 & $50 / 50$ & Low and high validation \\
\hline $304 \mathrm{~L}$ & 12 & New & Process verification (and 2 contingency) \\
\hline
\end{tabular}


Appendix A. Micrographs of Type 316 stem pinch welds used for set-up.
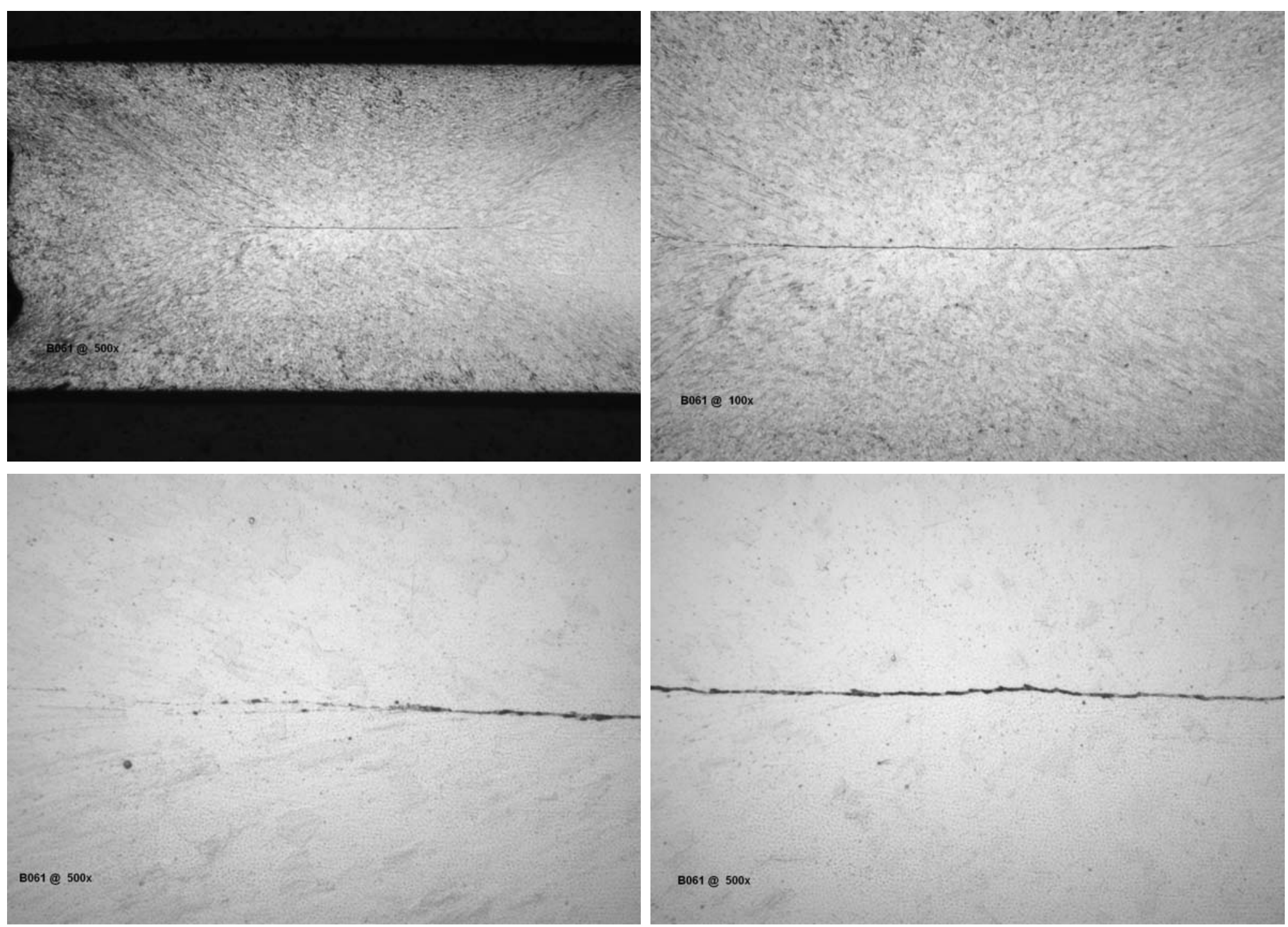

B061 Low 

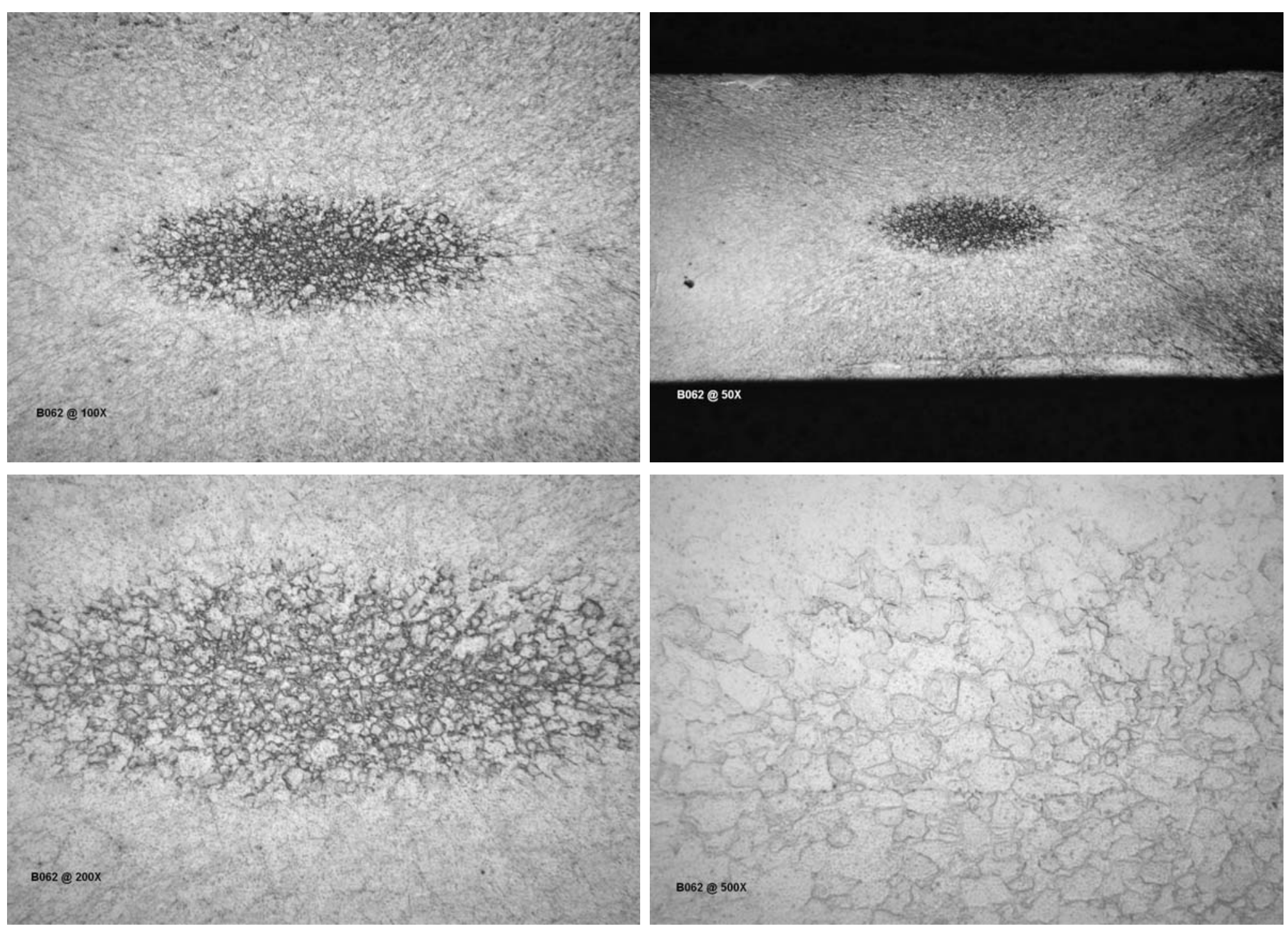

B062 Low 

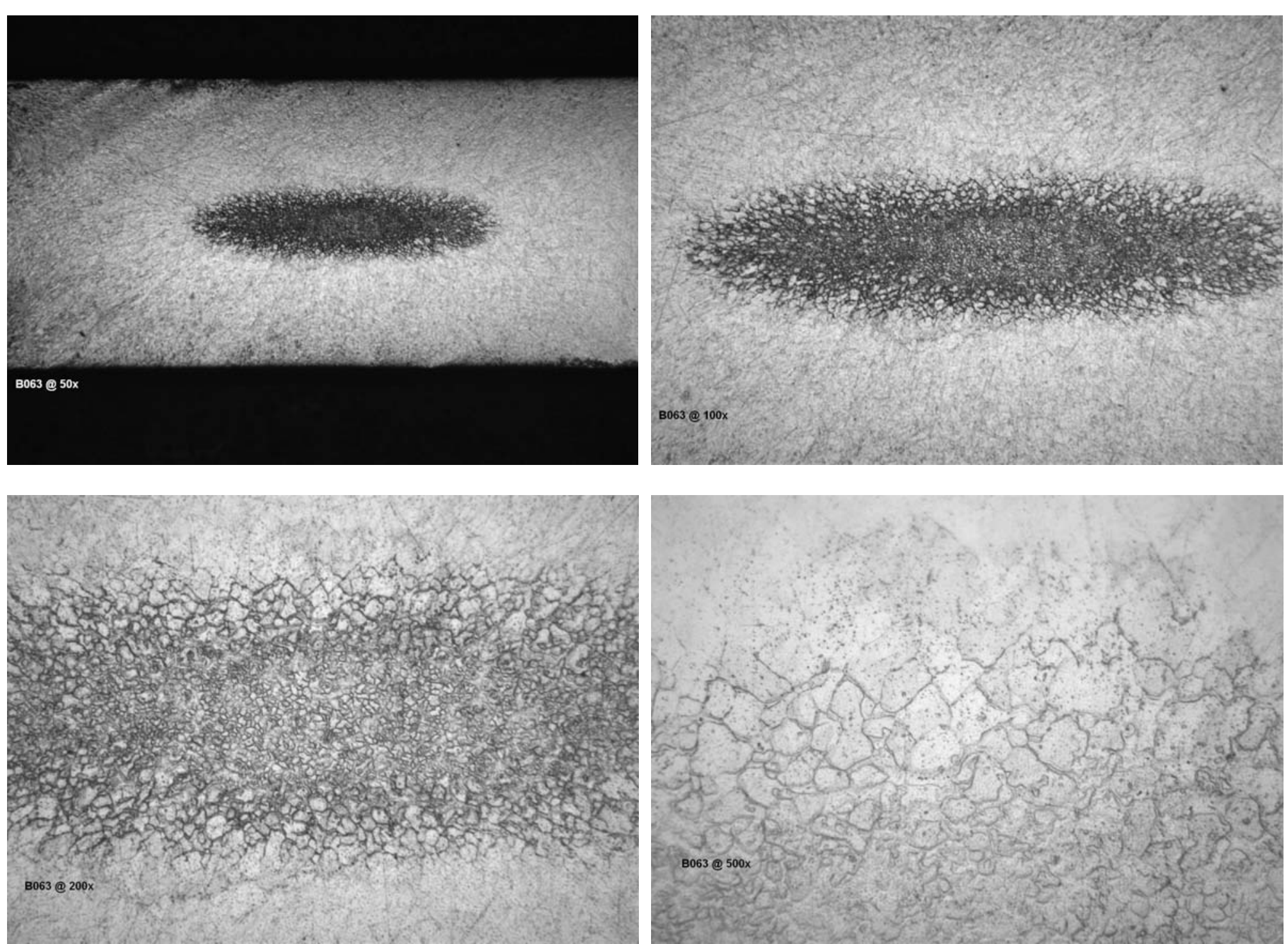

B063 High 
Appendix B. Micrographs of 21-6-9 stem pinch welds used for set-up.
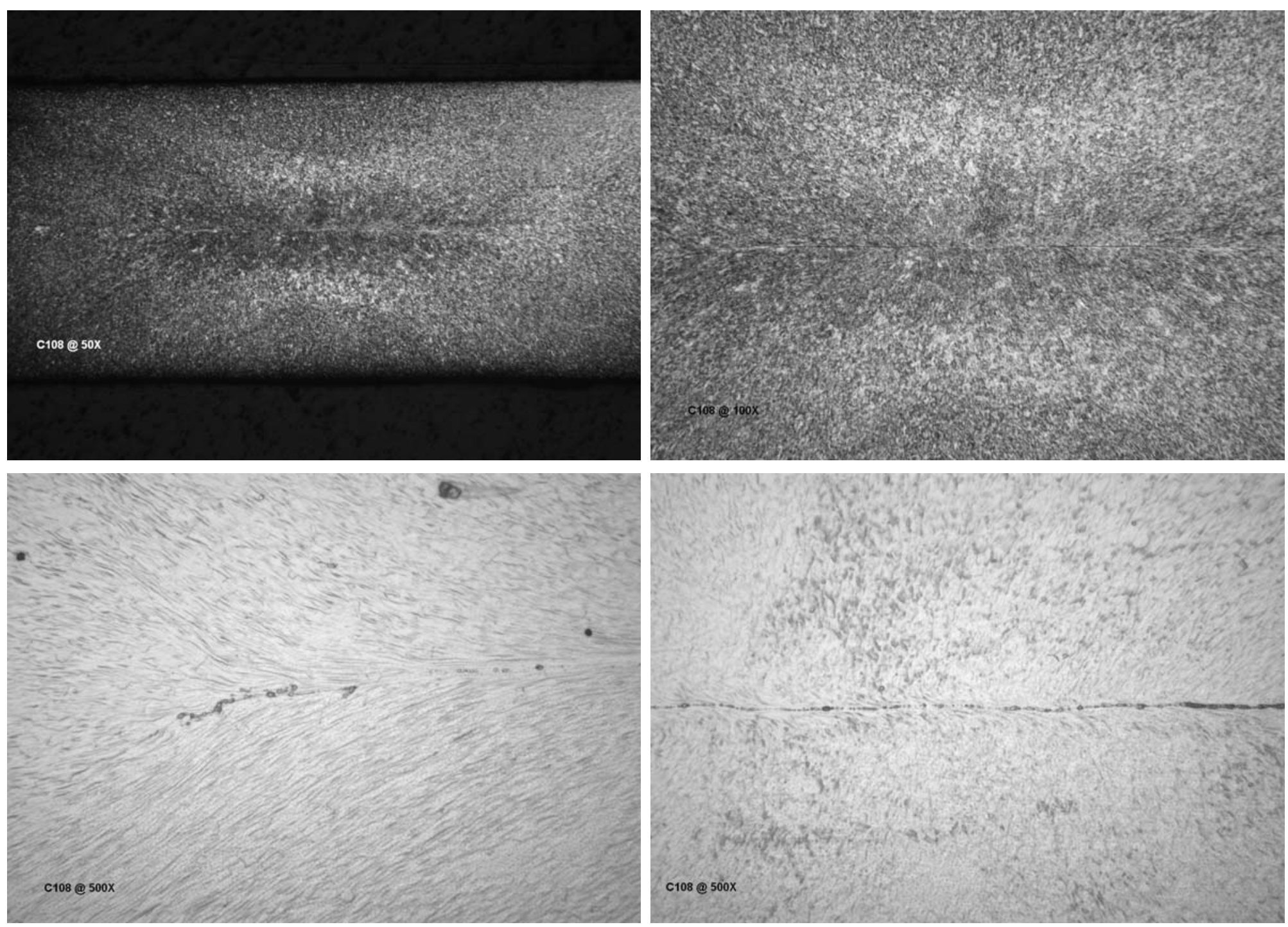

C108 Low 

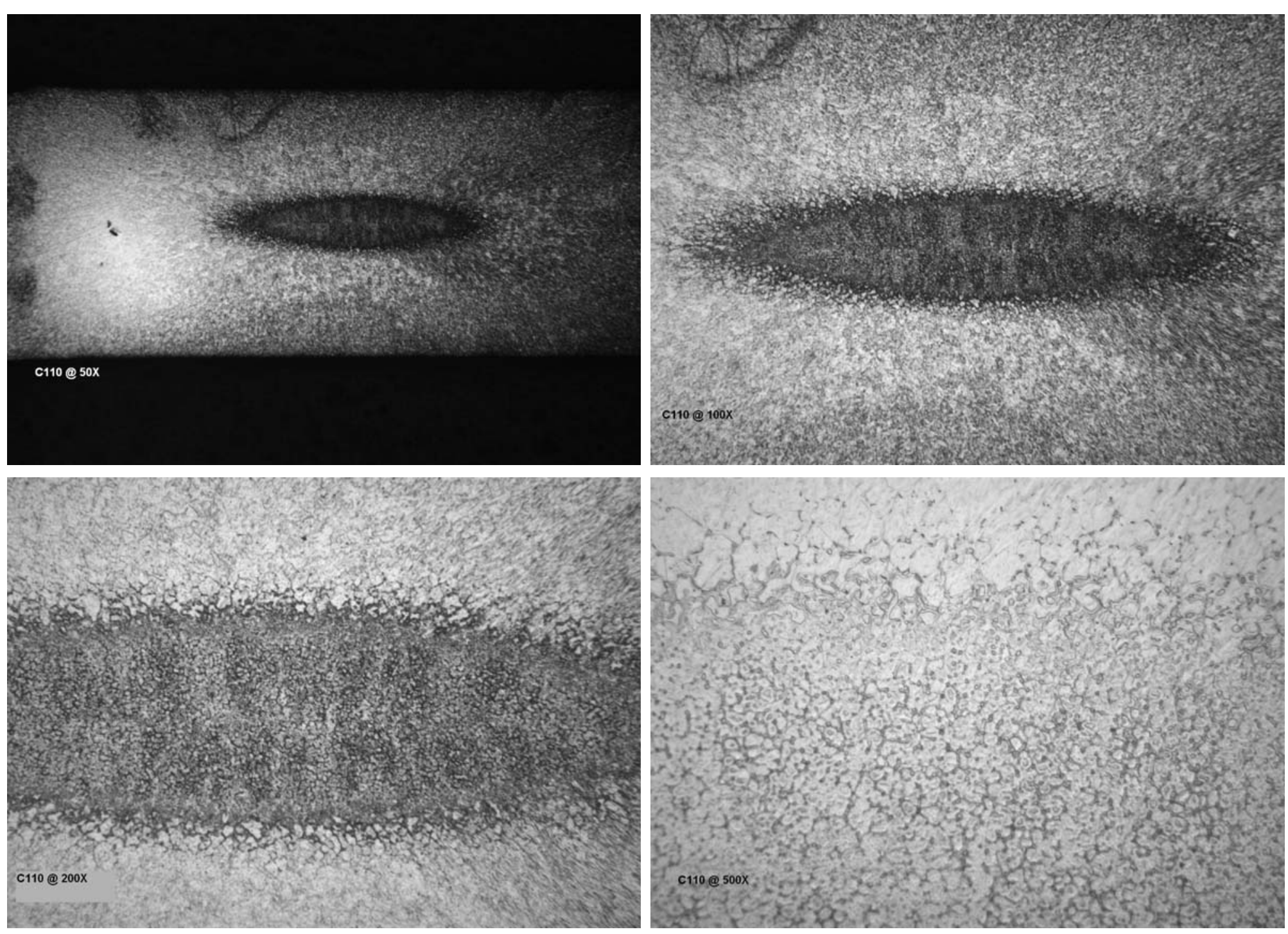

\section{C110 High}



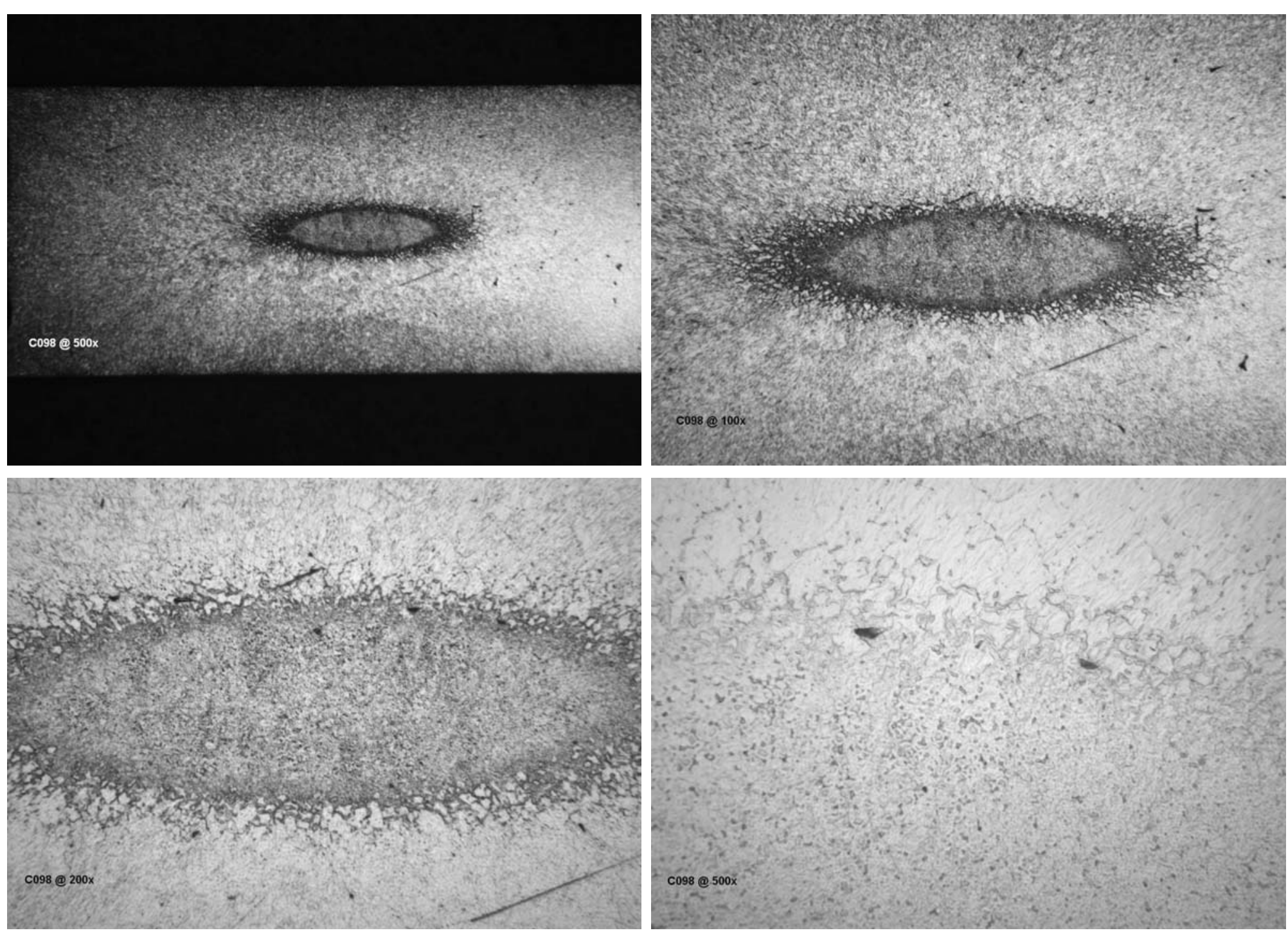

C098 High 


\section{Appendix C. Micrographs of Type 304L stem pinch welds used for set-up}
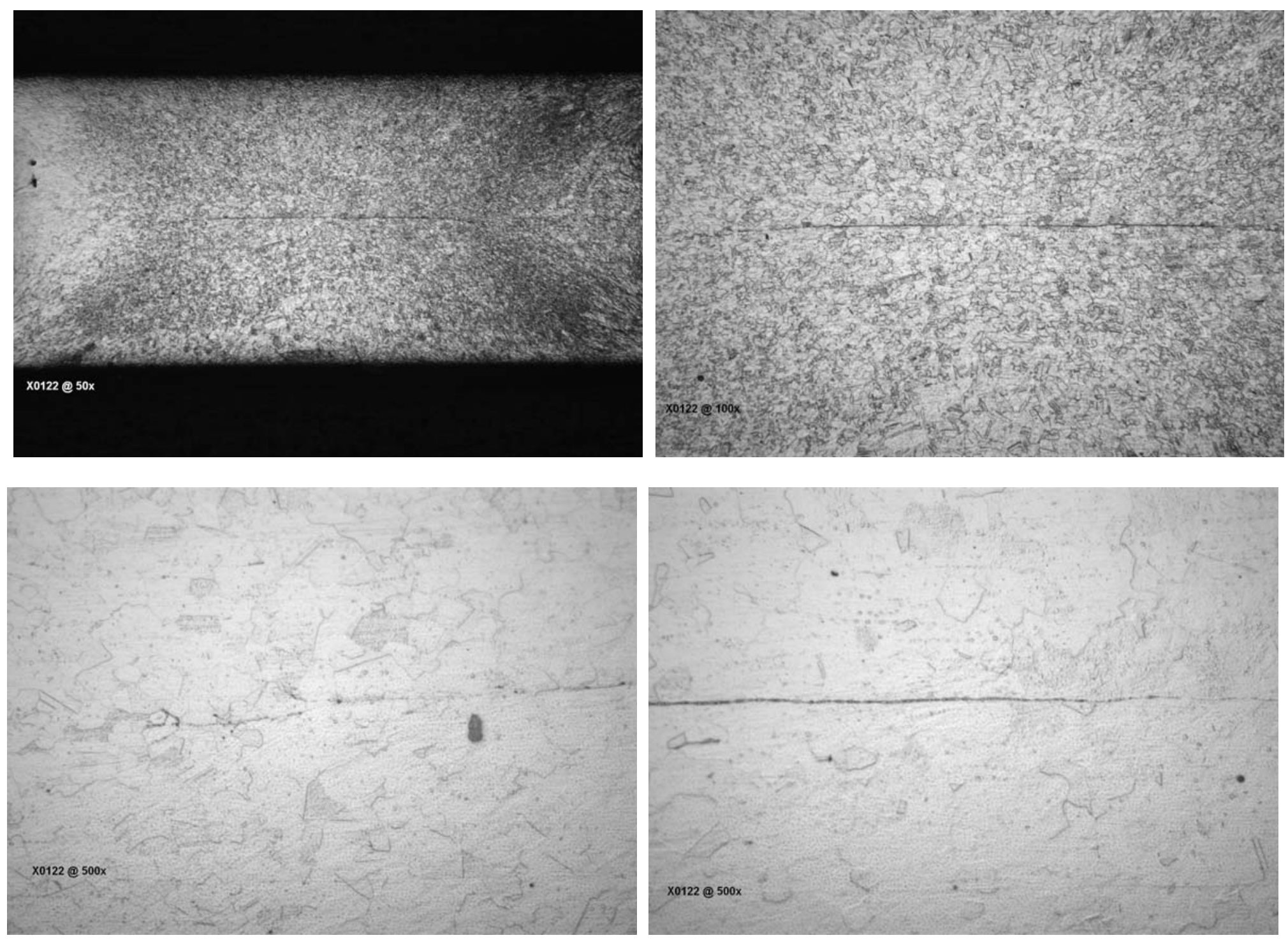

X0122 Low 

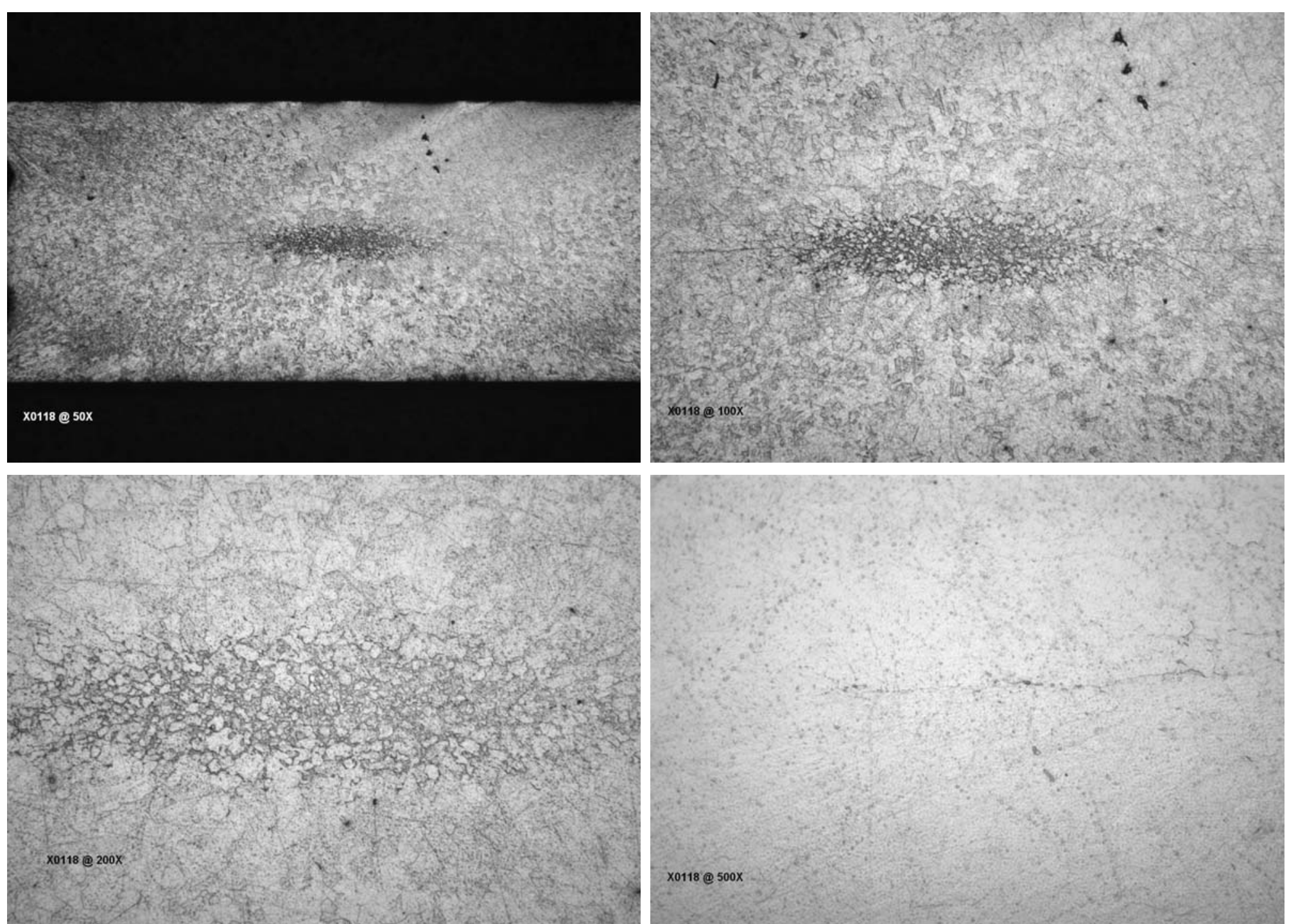

X0118 High 
Appendix D. Micrographs of Type 316 stainless steel stems used for weld window verification.
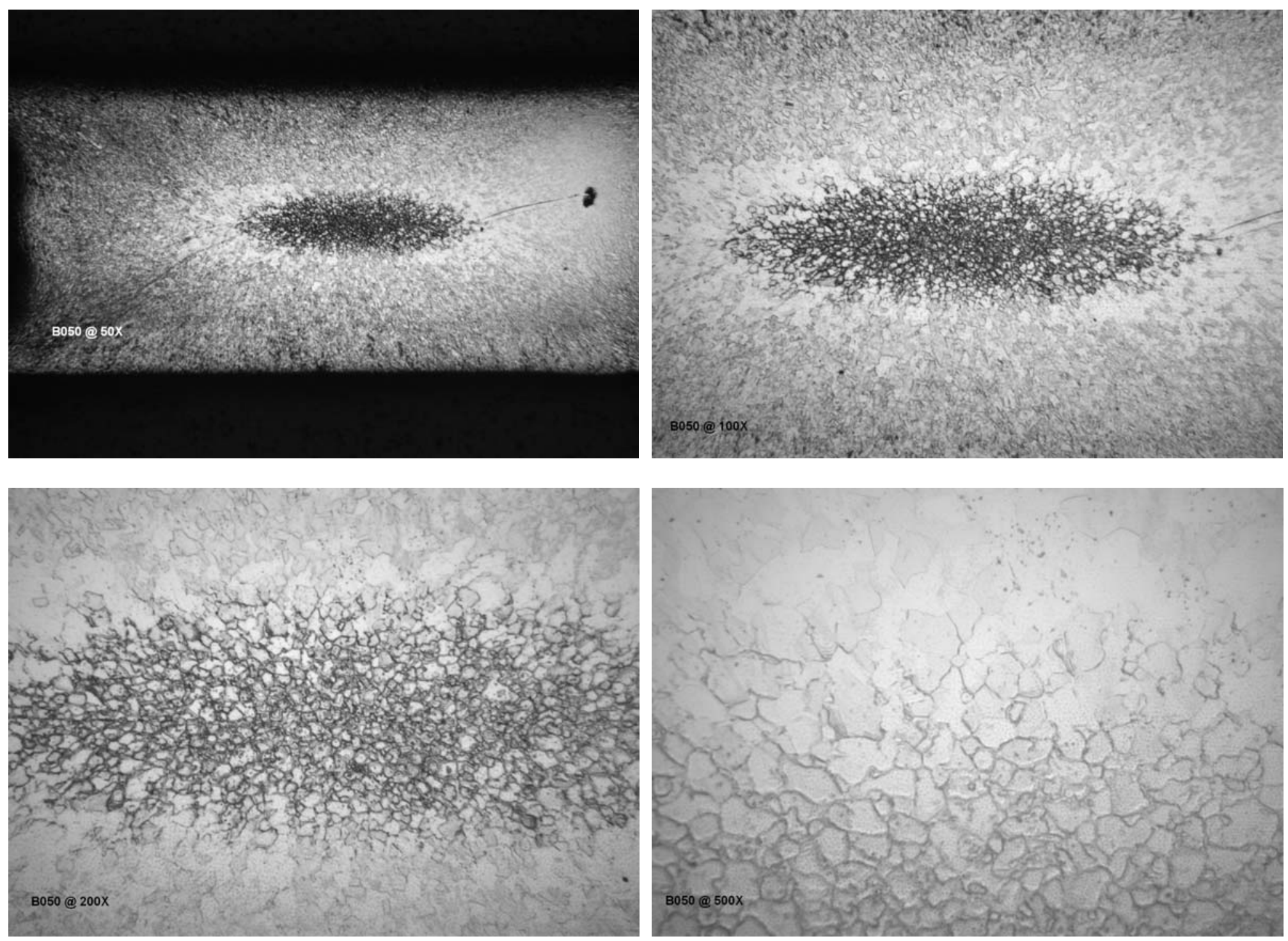

B050 Low 

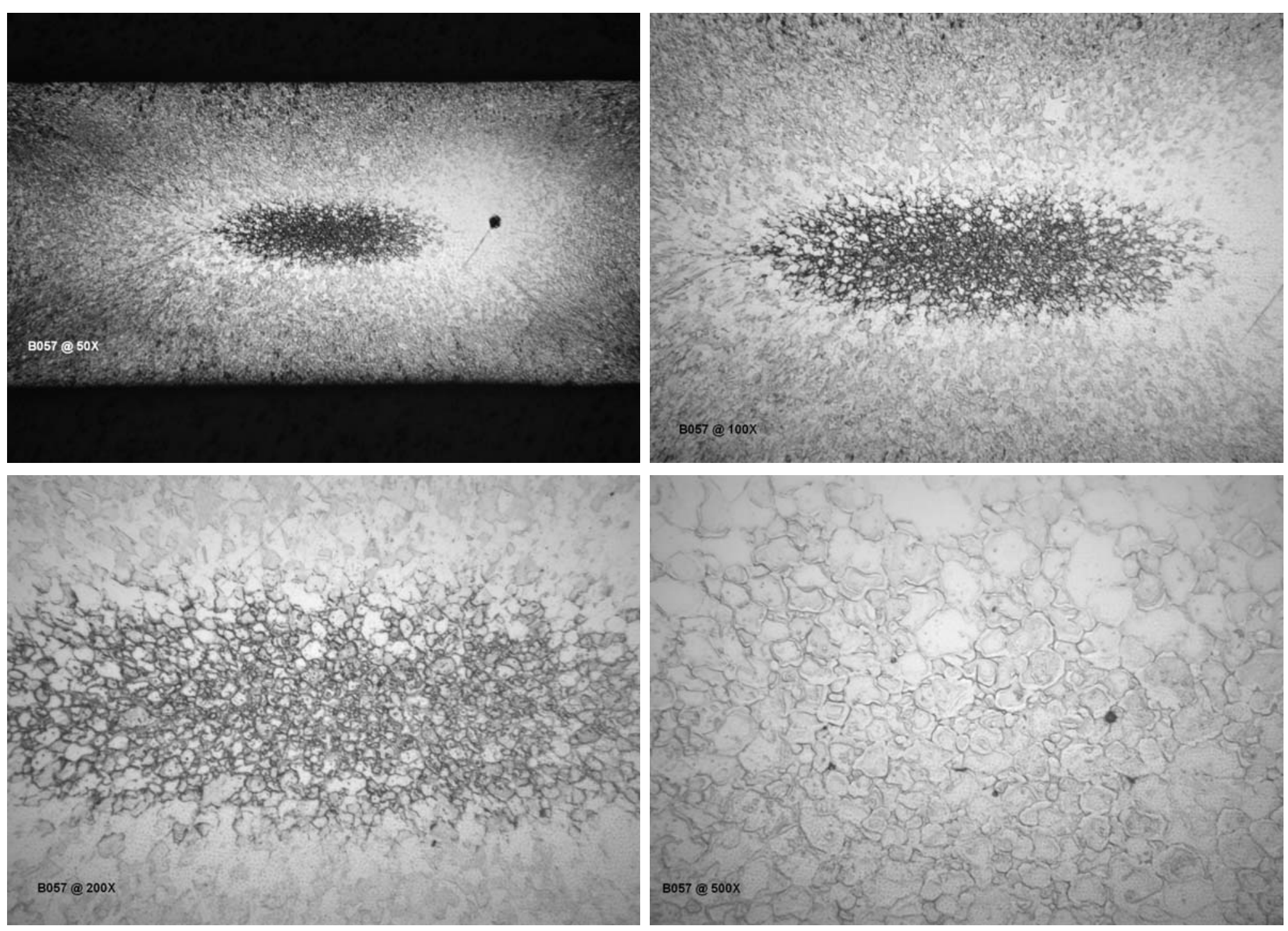

B057 Low 

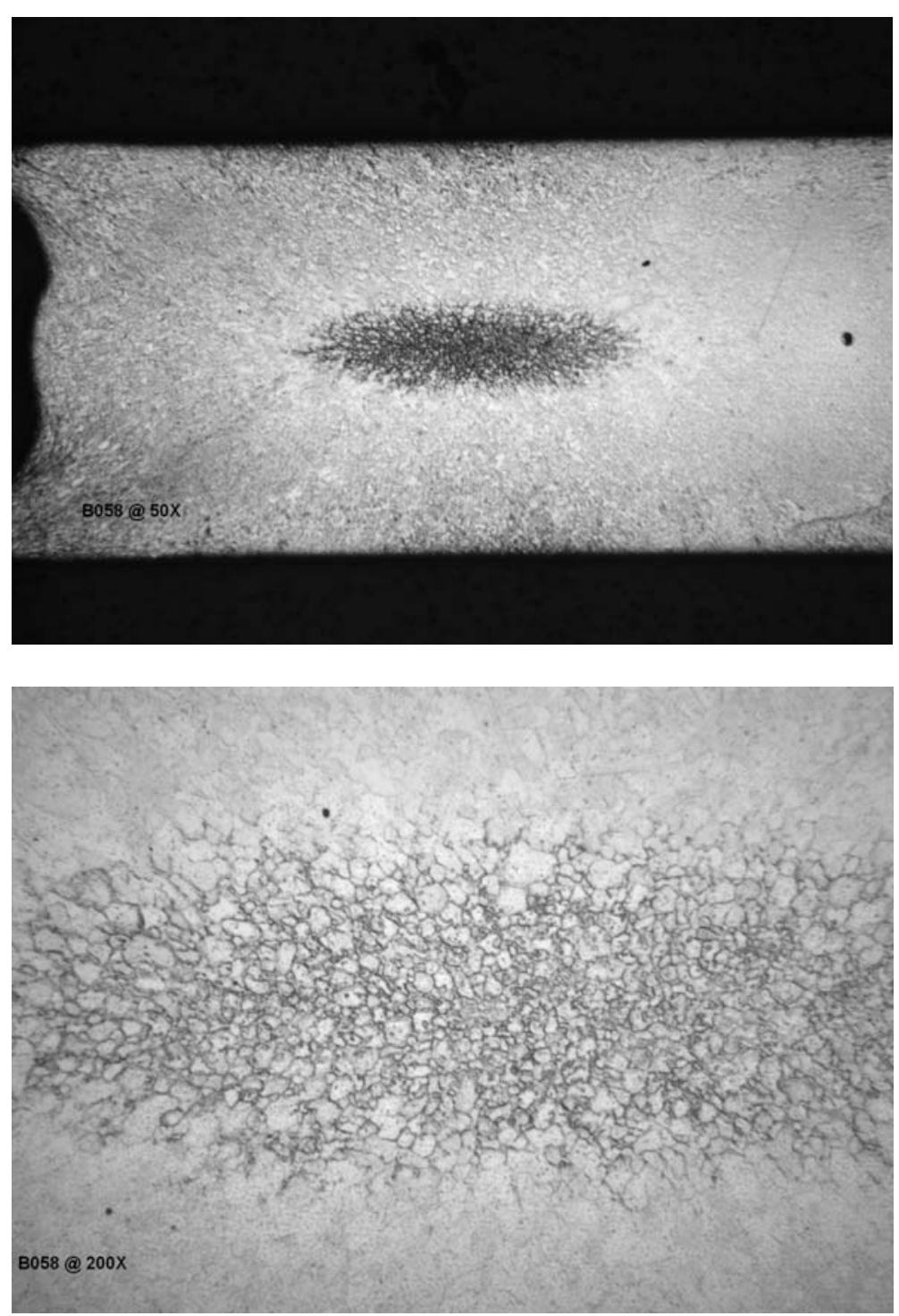

Page 18 of 33
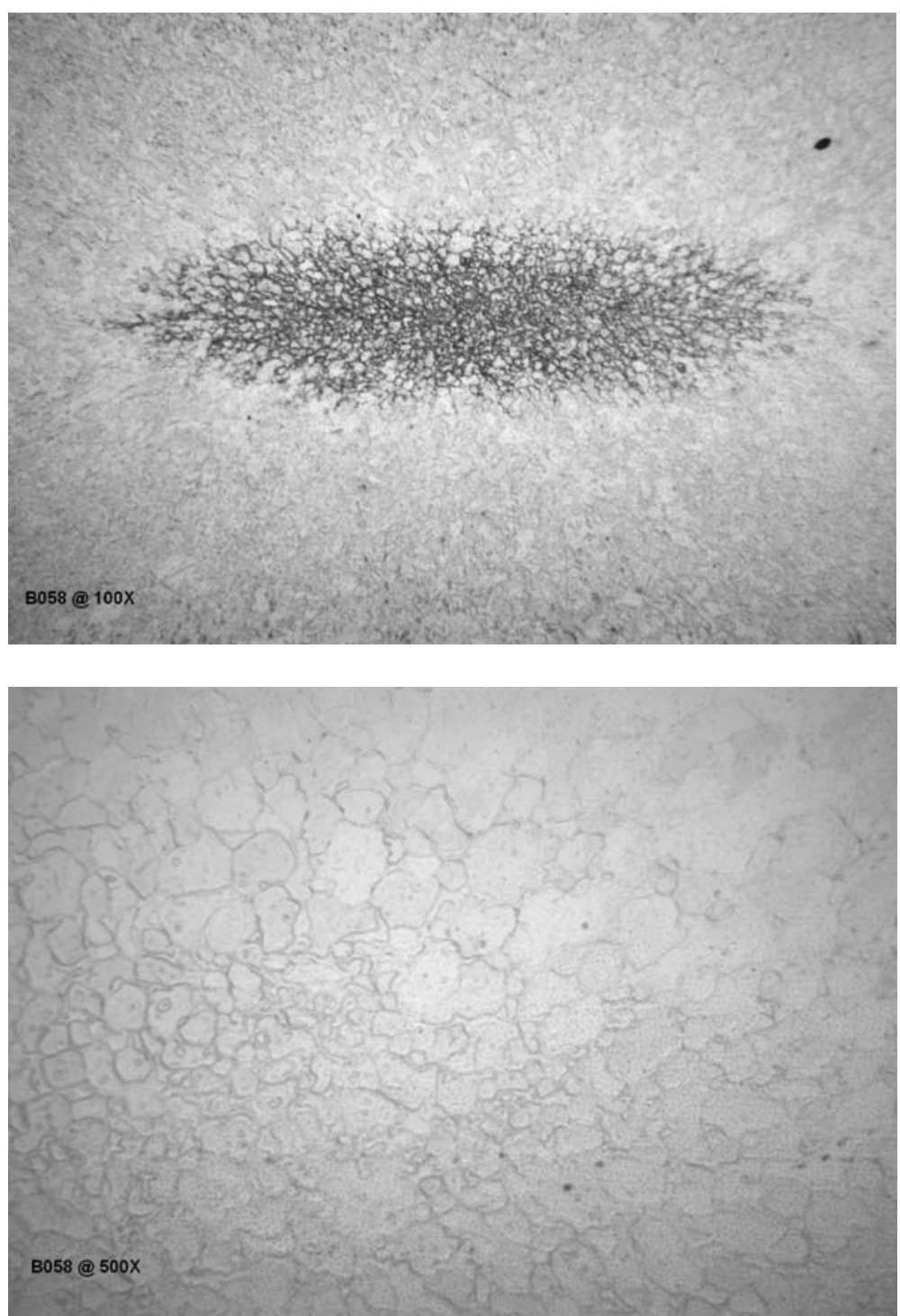

\section{B058 Low}


WSRC-STI-2008-00098
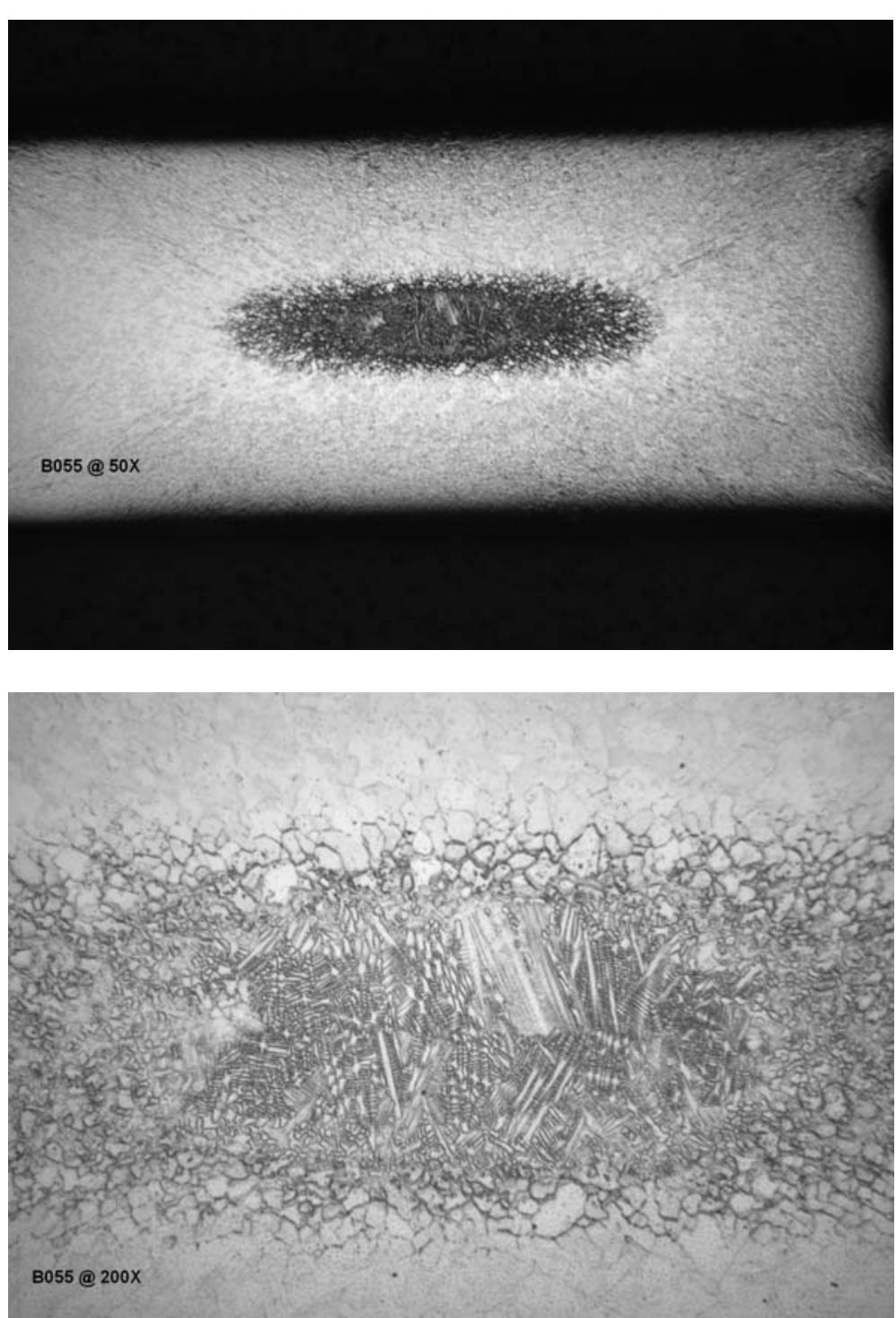

Page 19 of 33
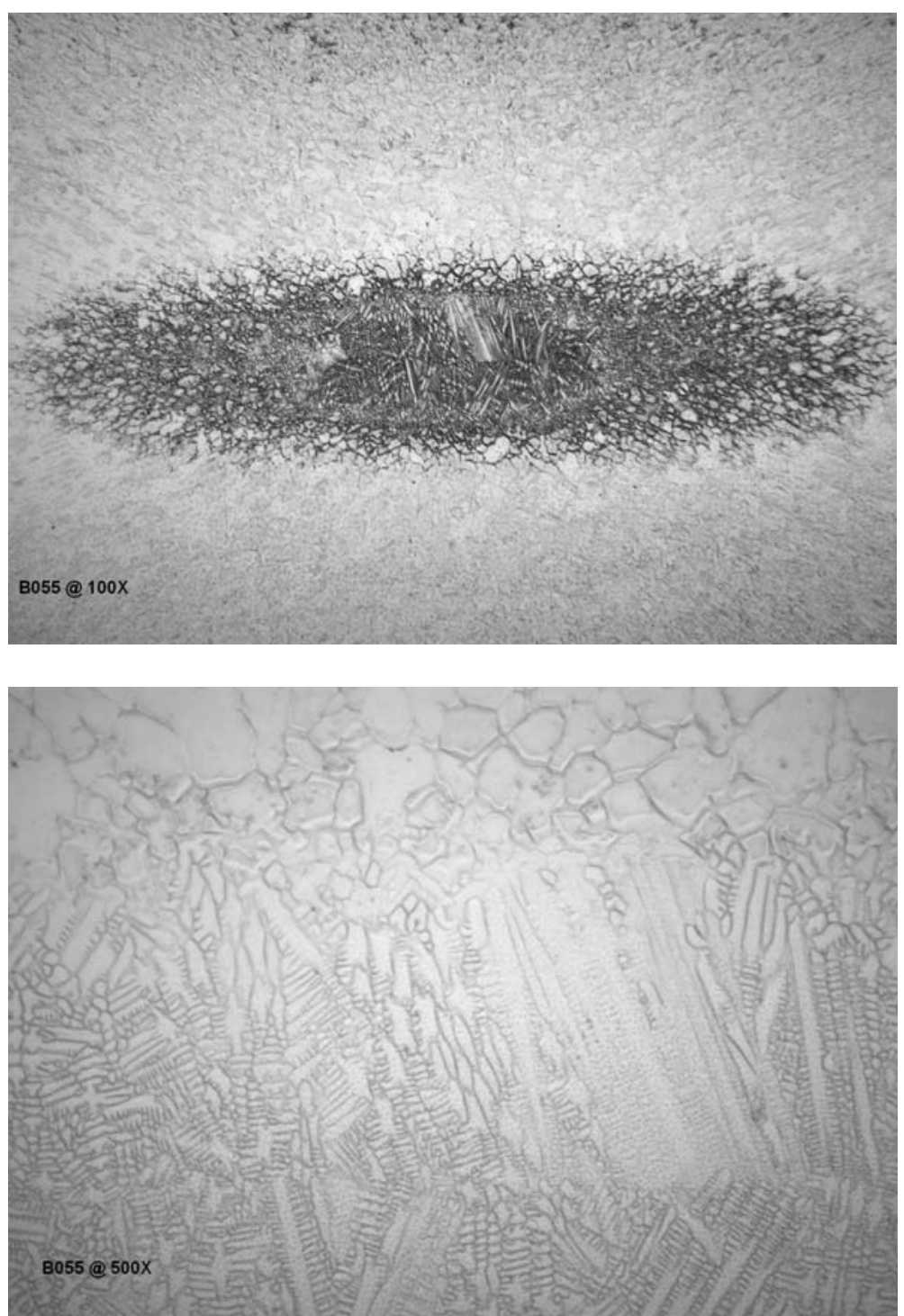

B055 High 

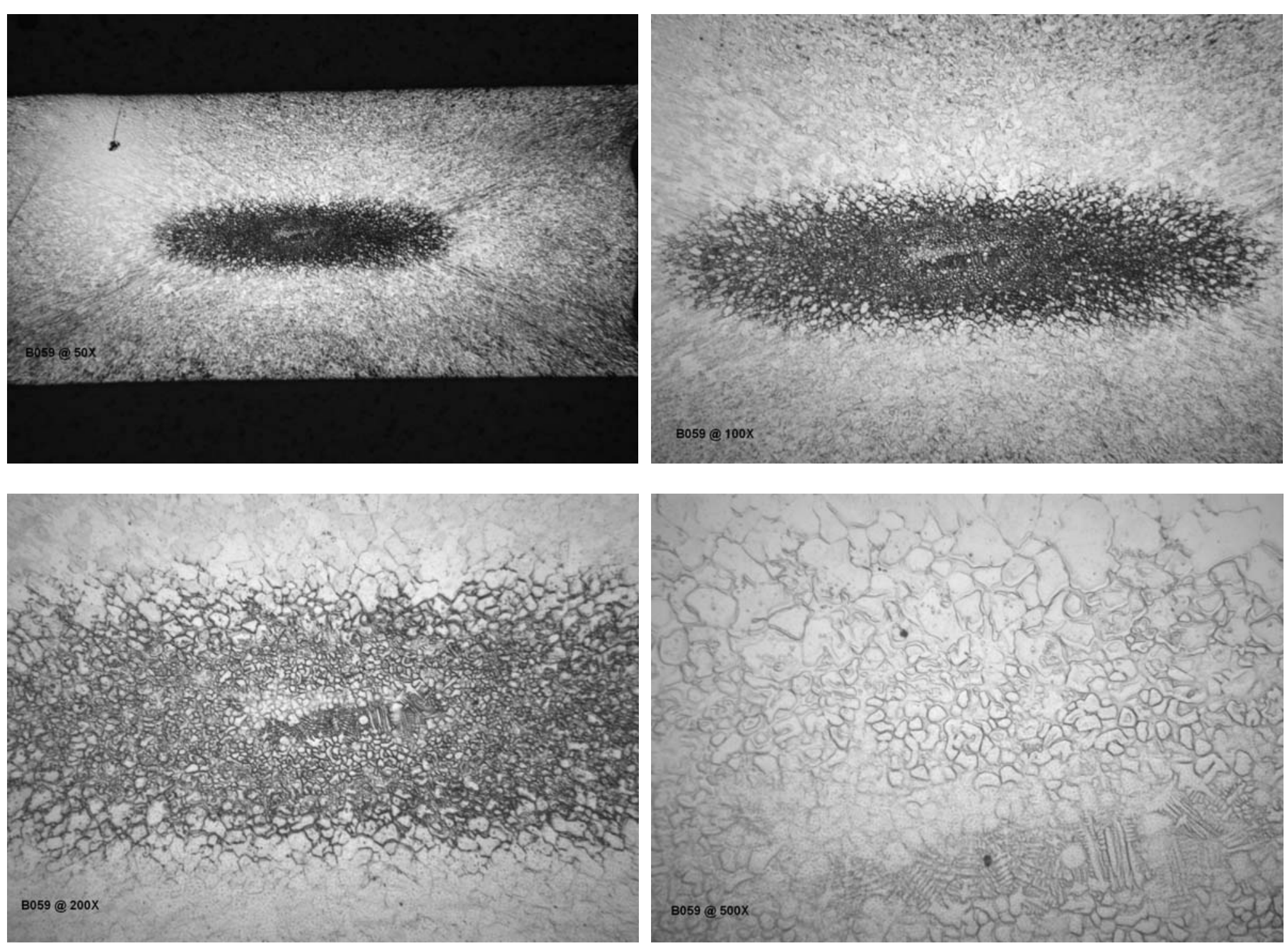

B059 High 

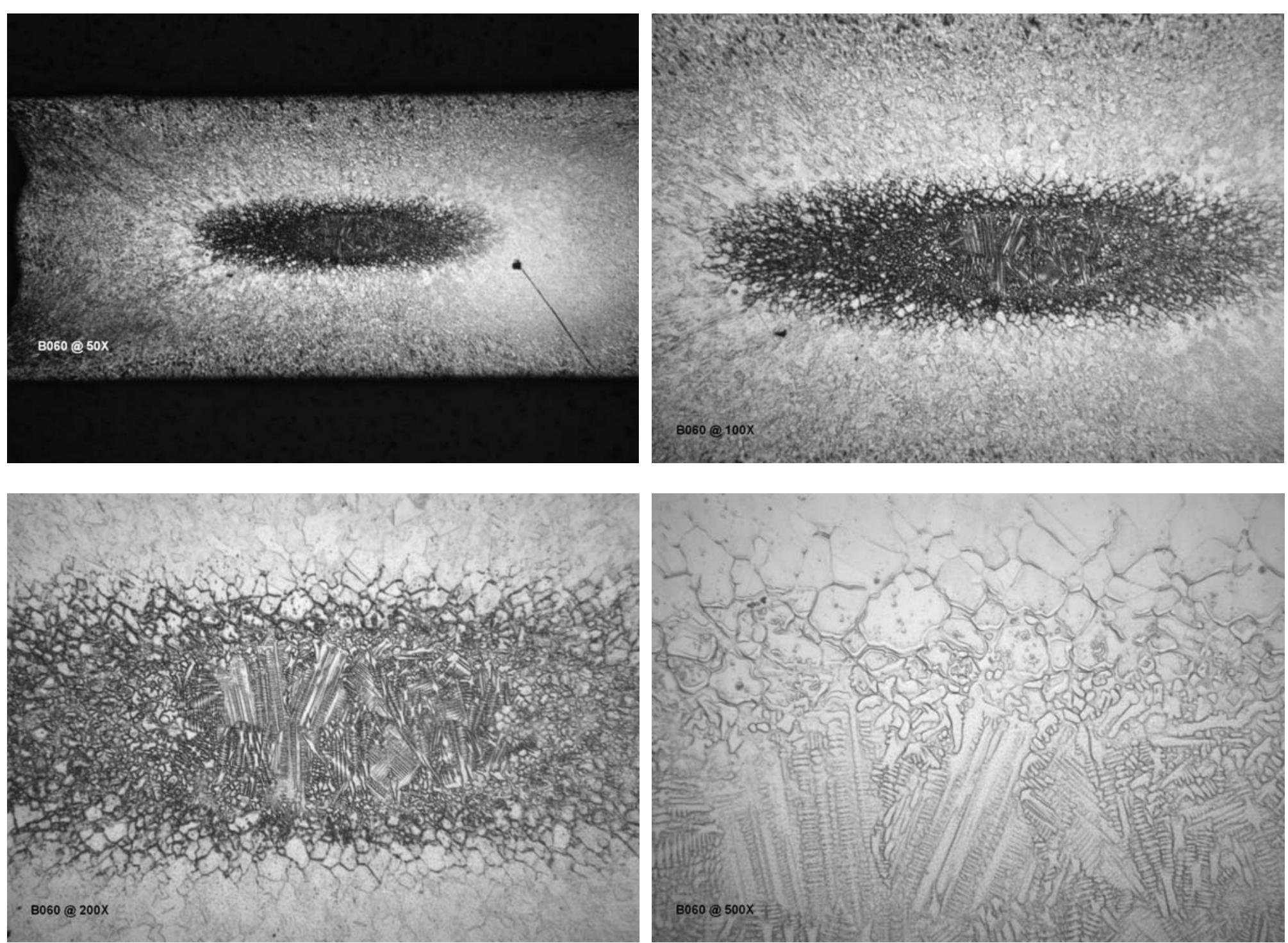

B060 High 

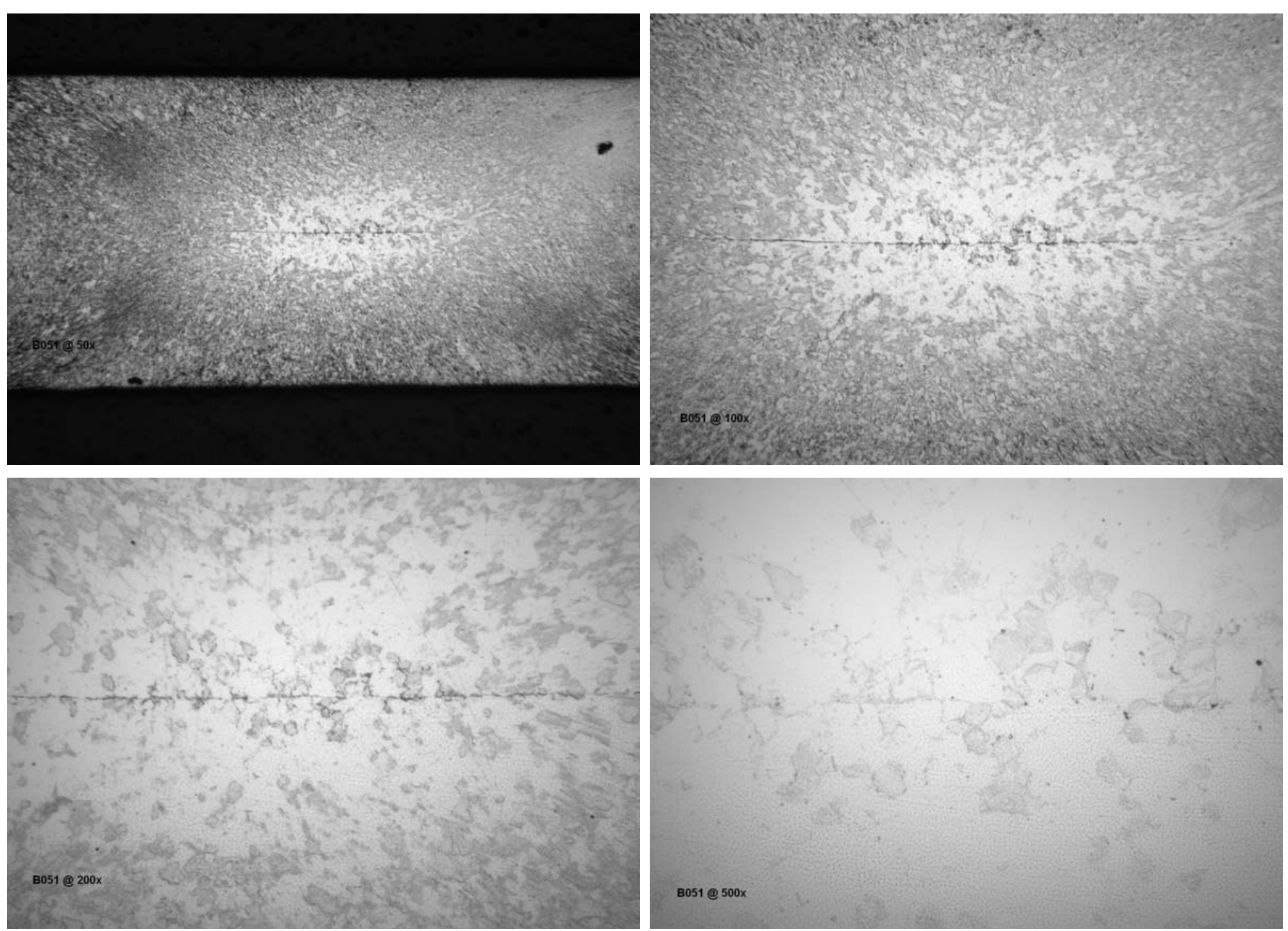

B051 New Cold Weld Condition 

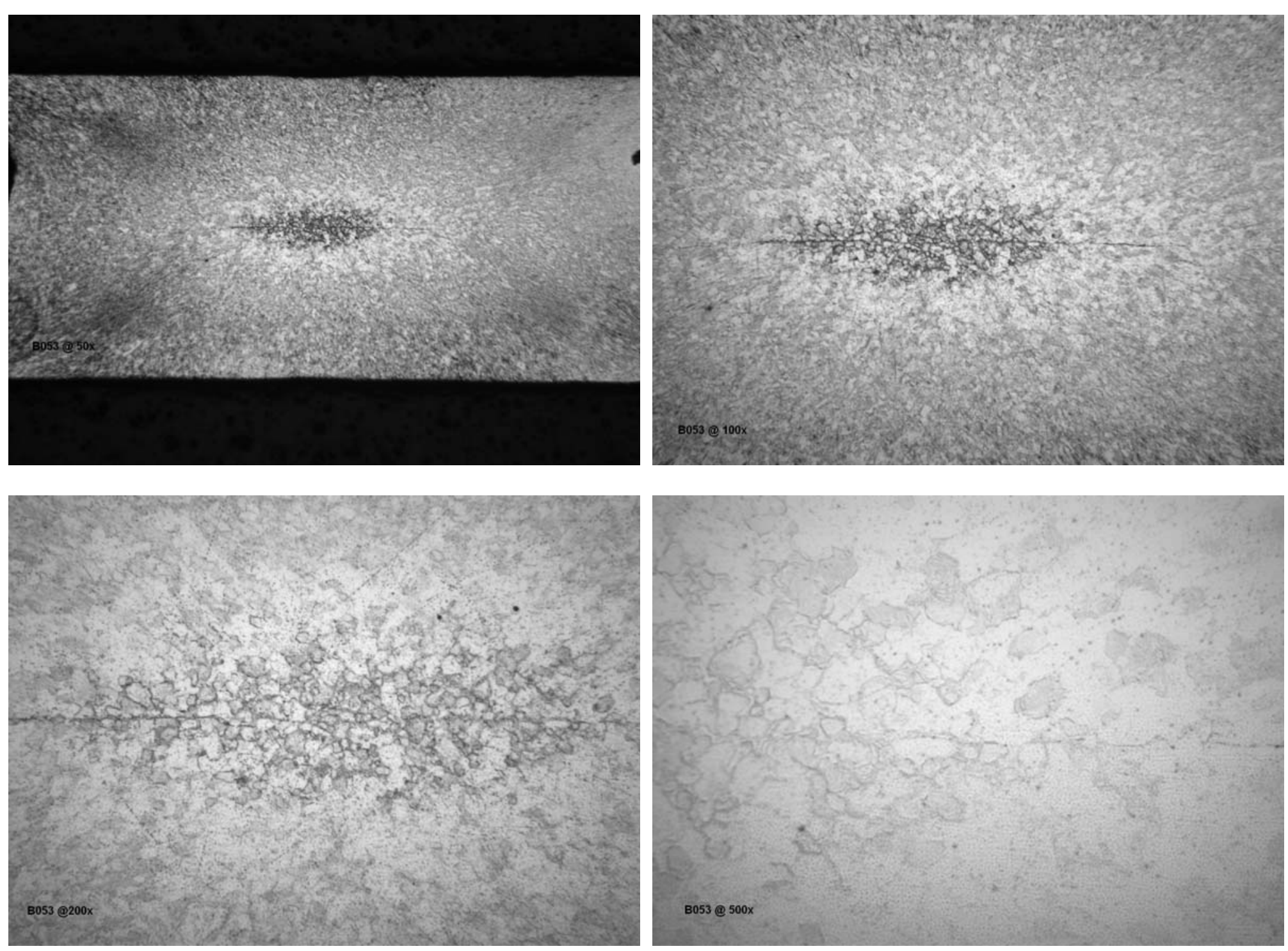

B053 New Cold Weld Condition 
Appendix E. Micrographs of 21-6-9 stainless steel stems used for weld window verification.
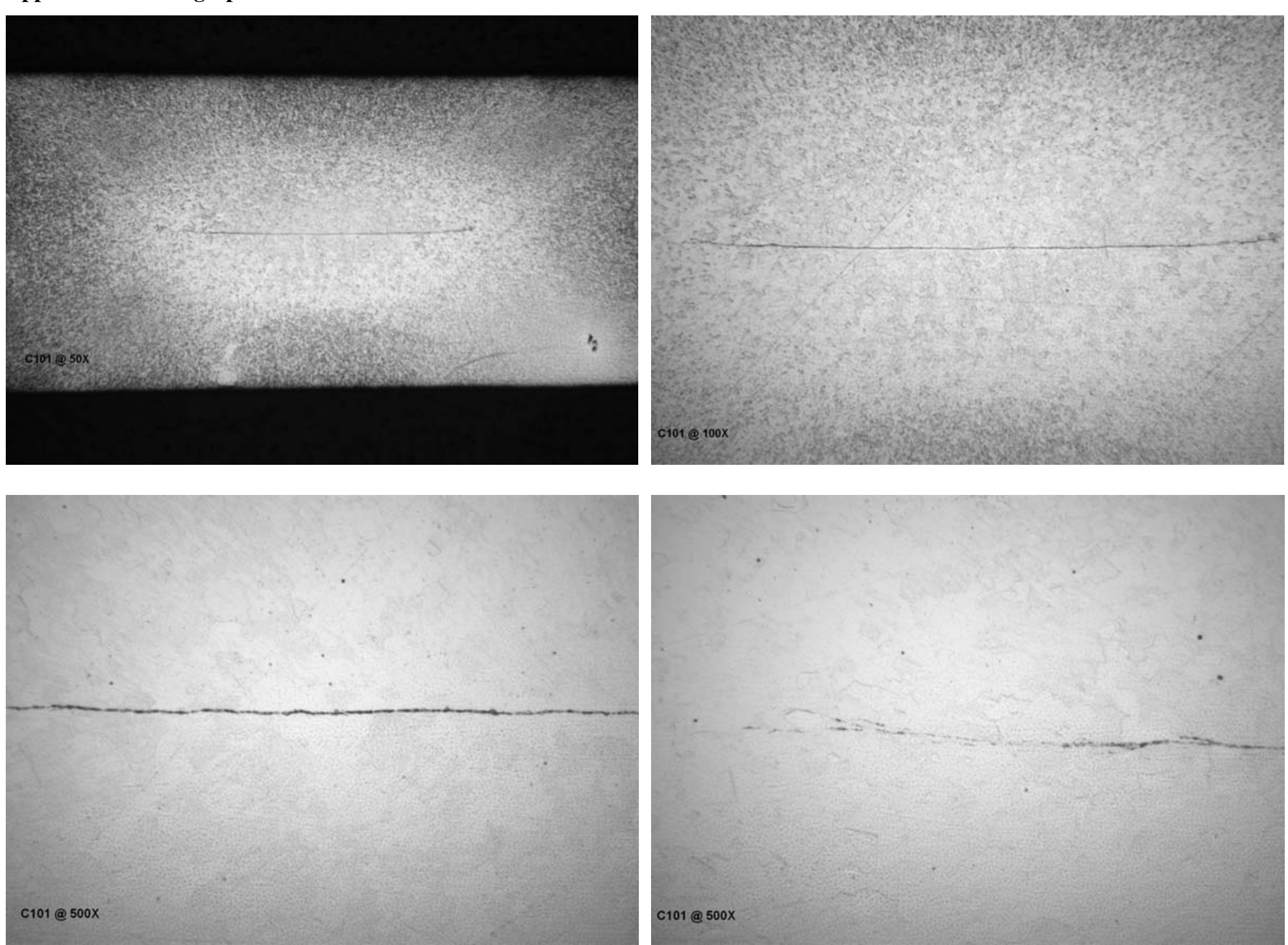

\section{C101 Low}


WSRC-STI-2008-00098
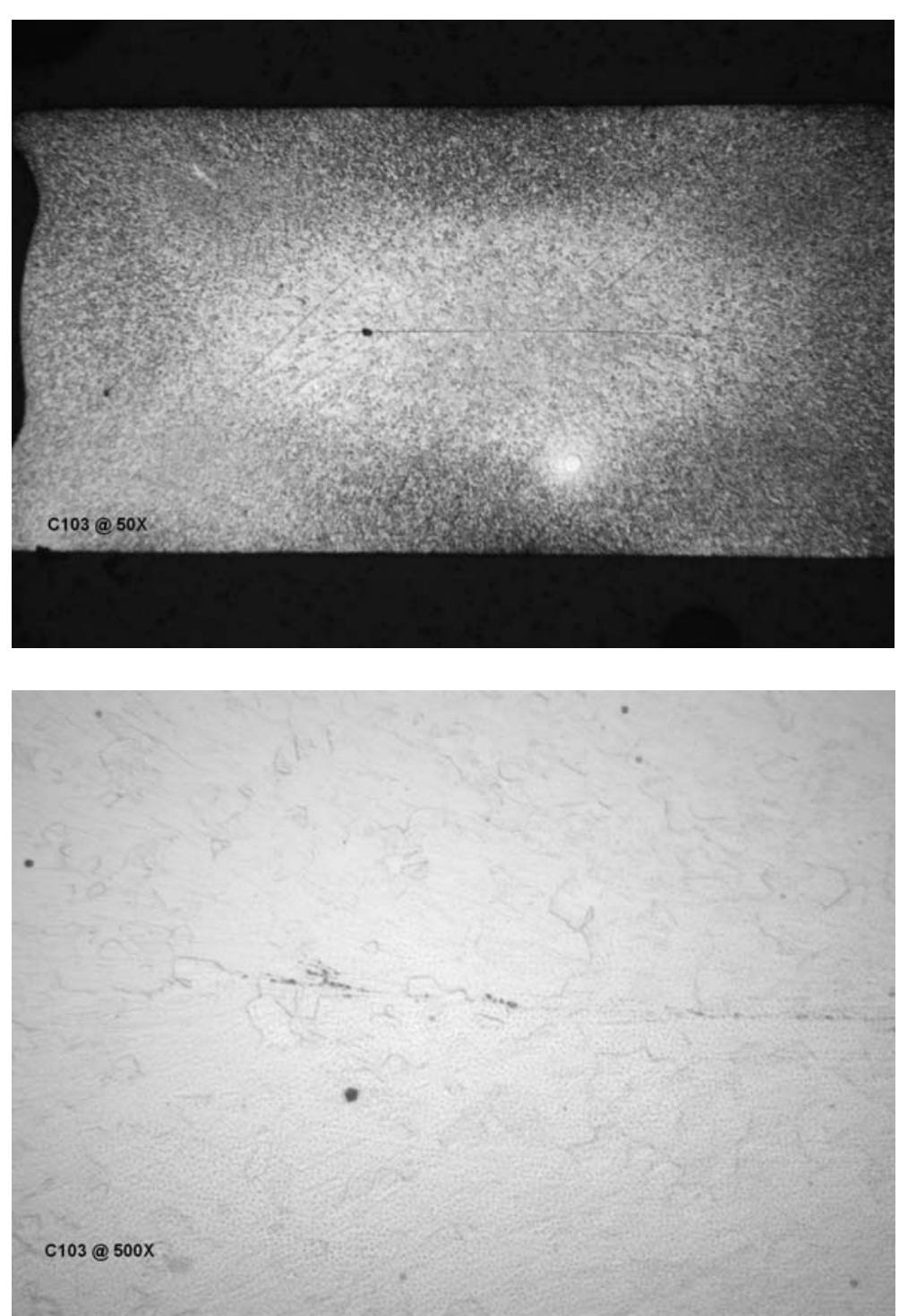

ci03@ $500 x$

Page 25 of 33
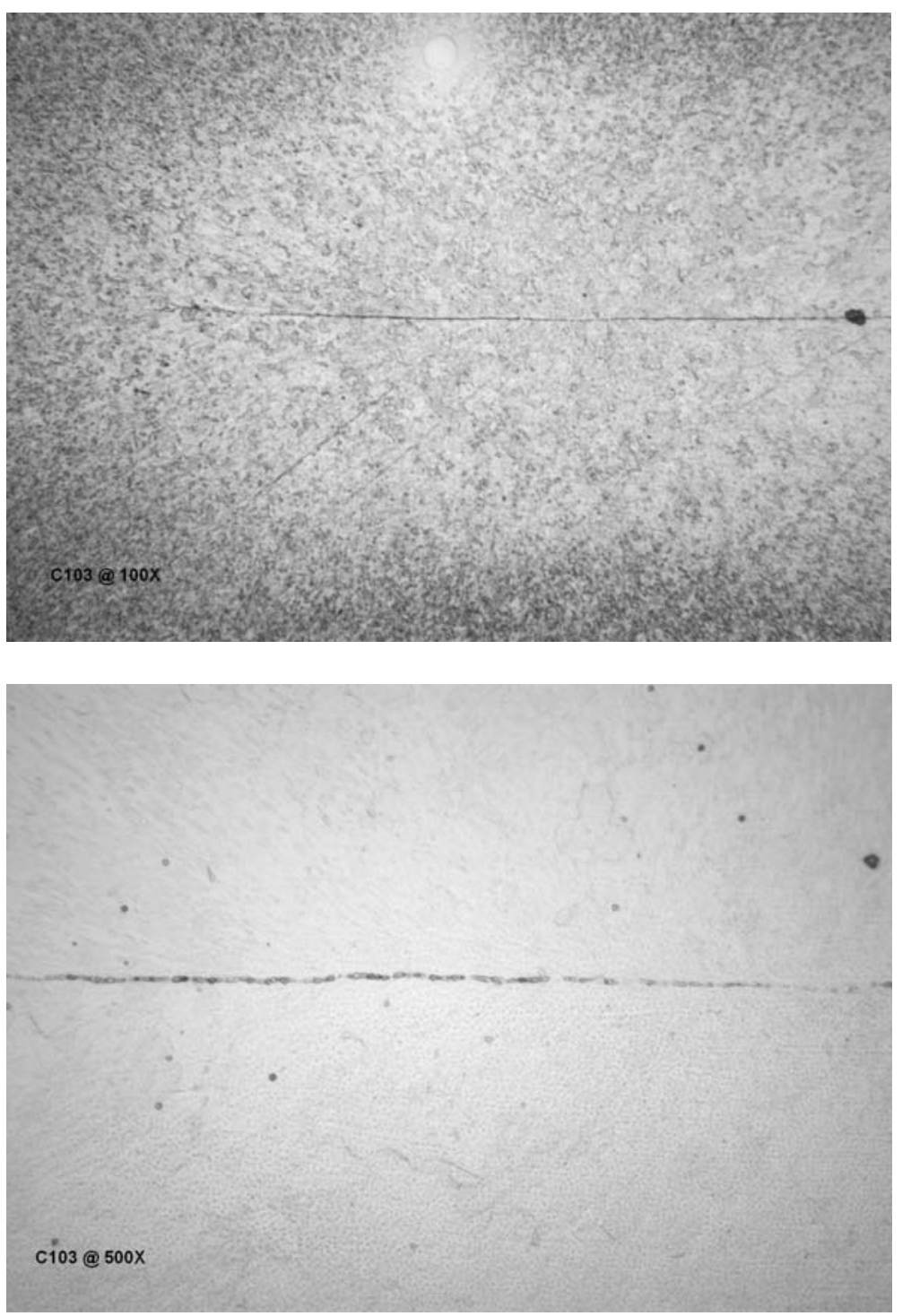

\section{C103 Low}



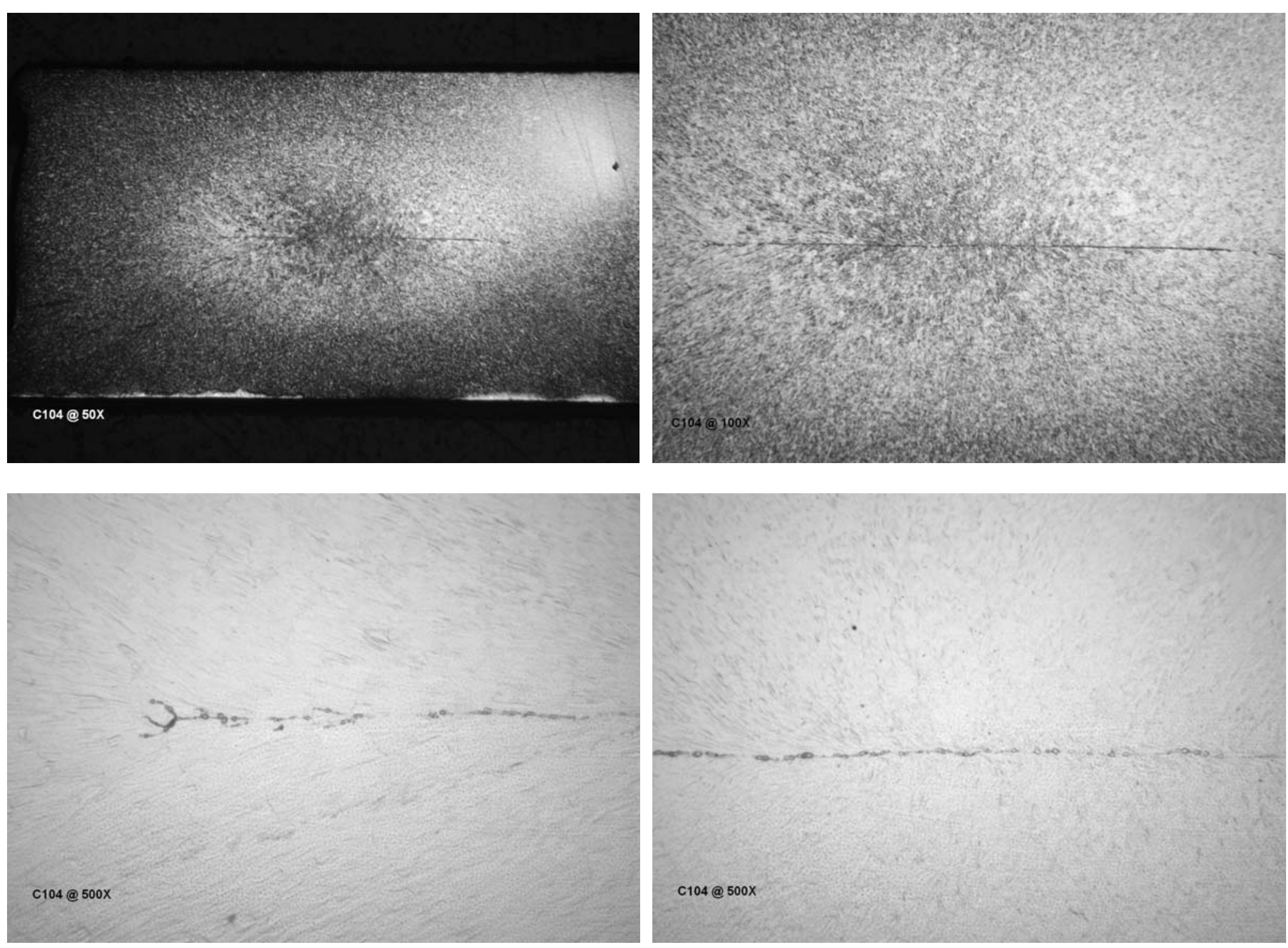

\section{C104 Low}


WSRC-STI-2008-00098
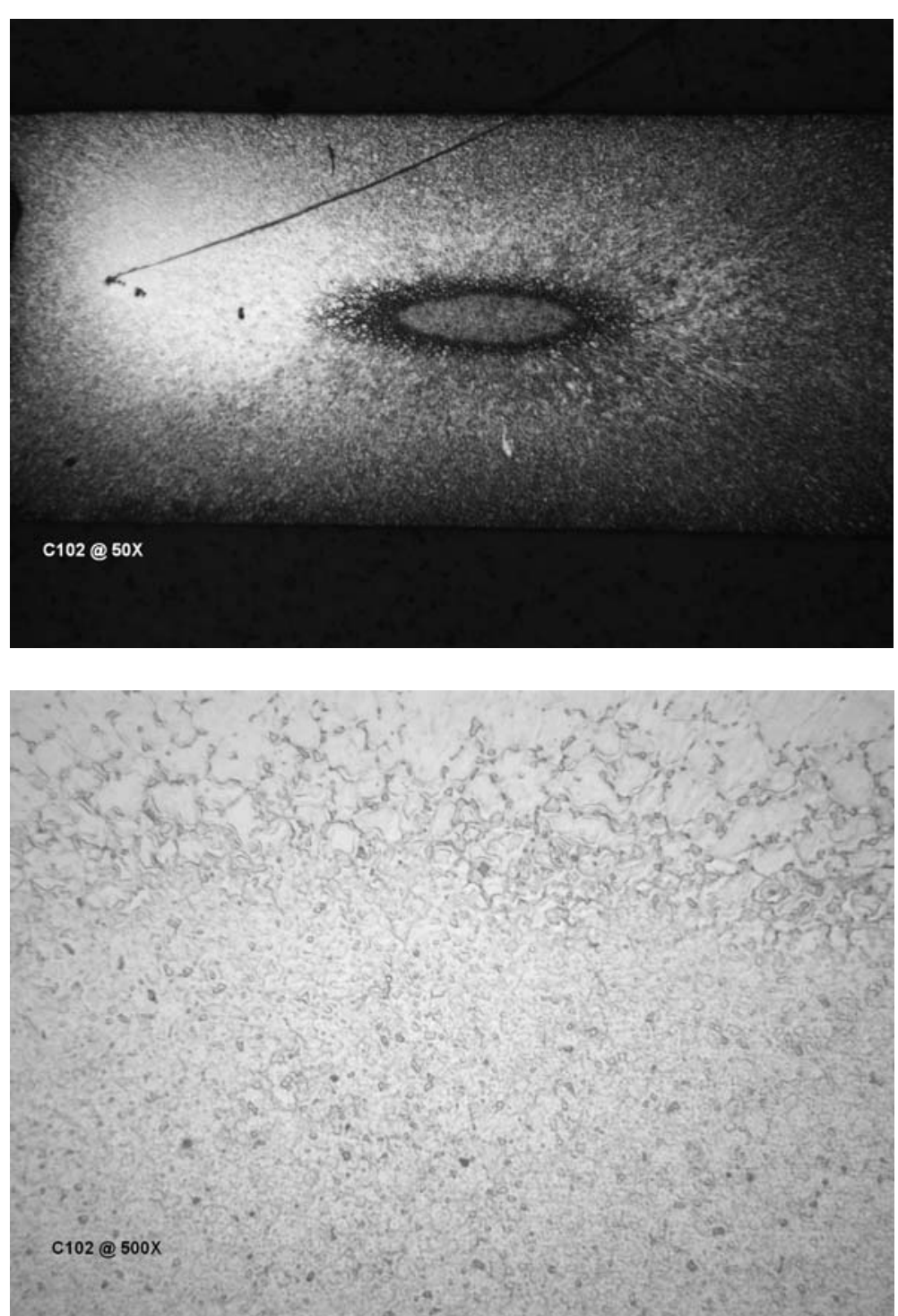

Page 27 of 33
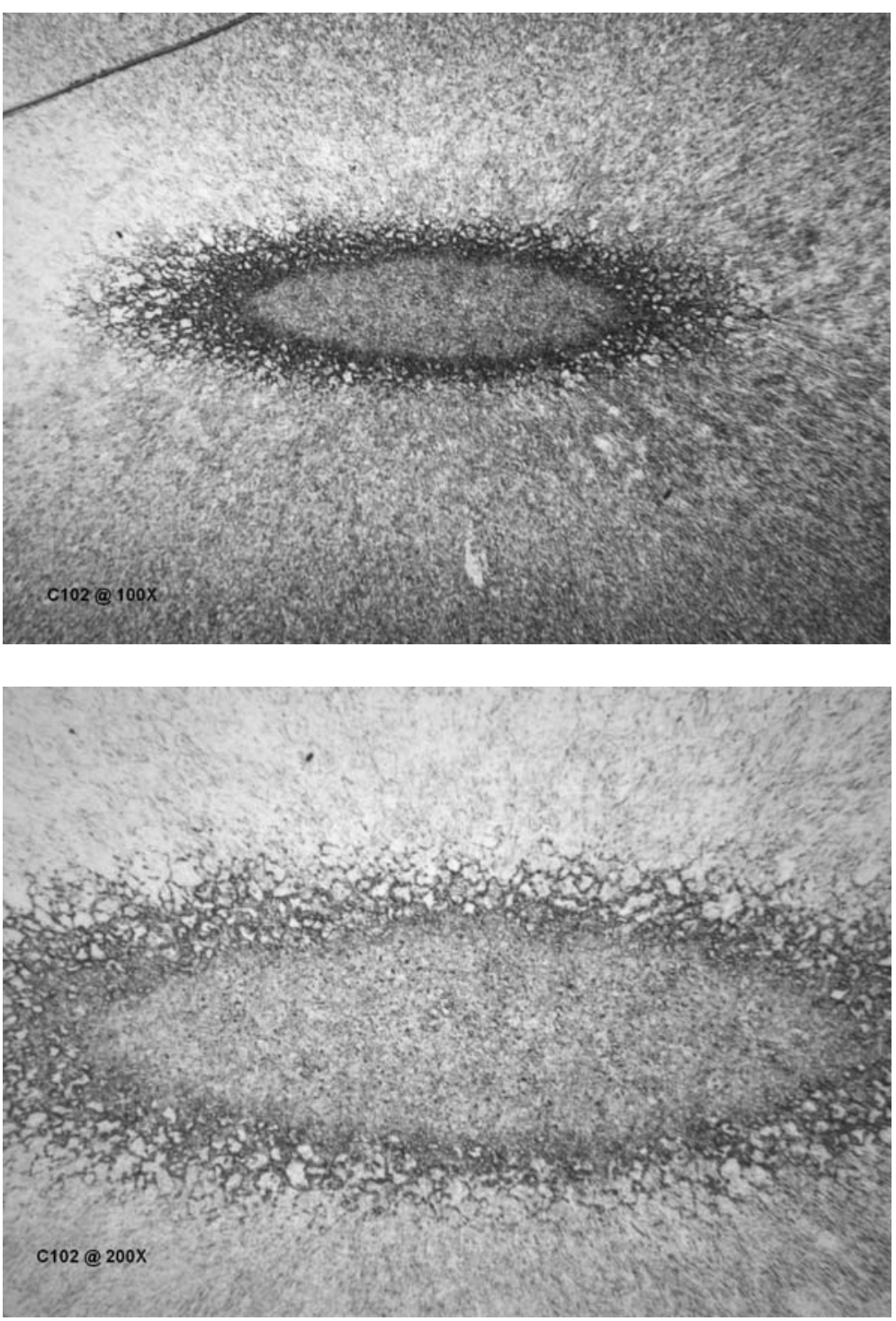

C102 High 

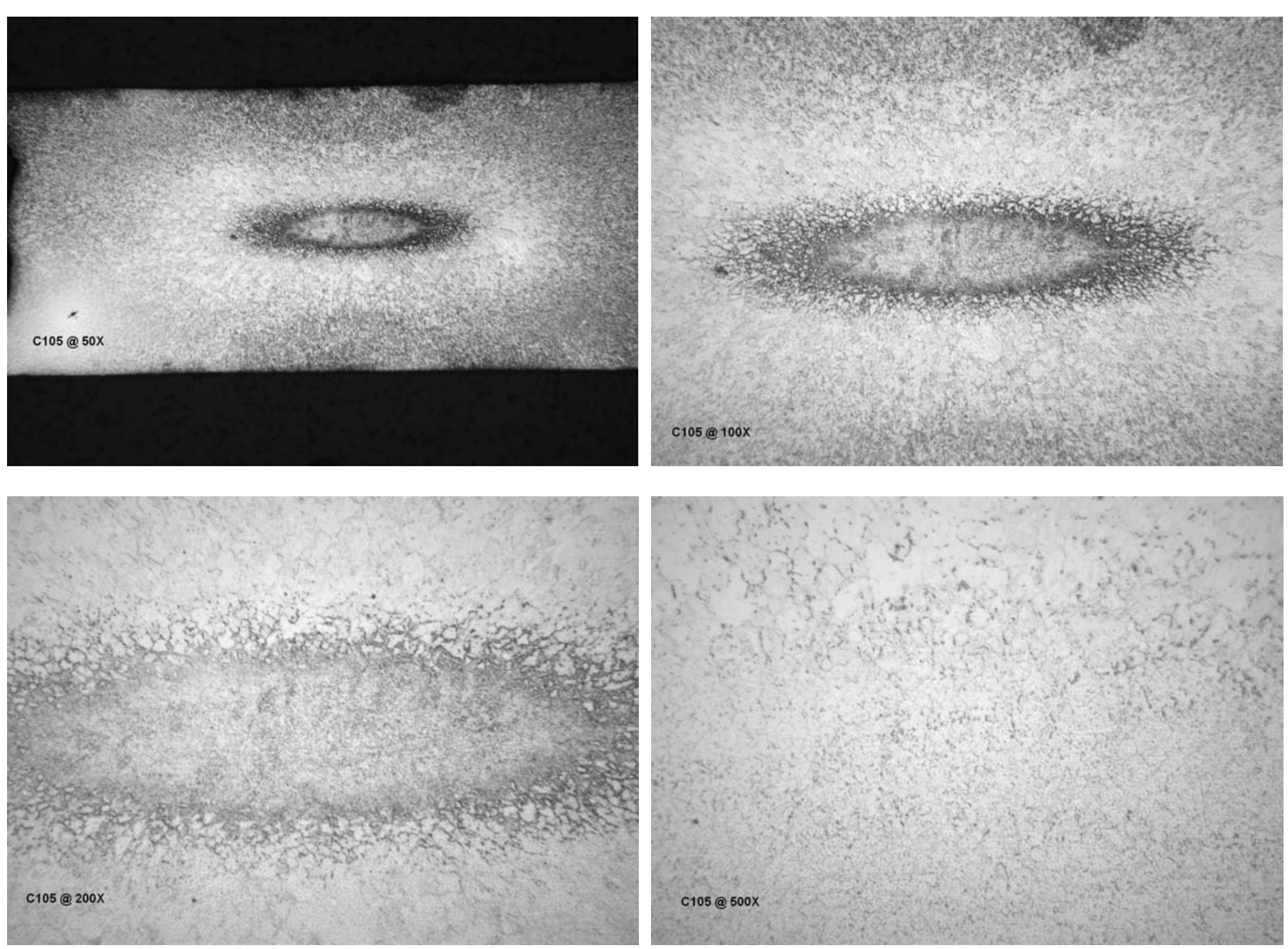

C105 High 
WSRC-STI-2008-00098
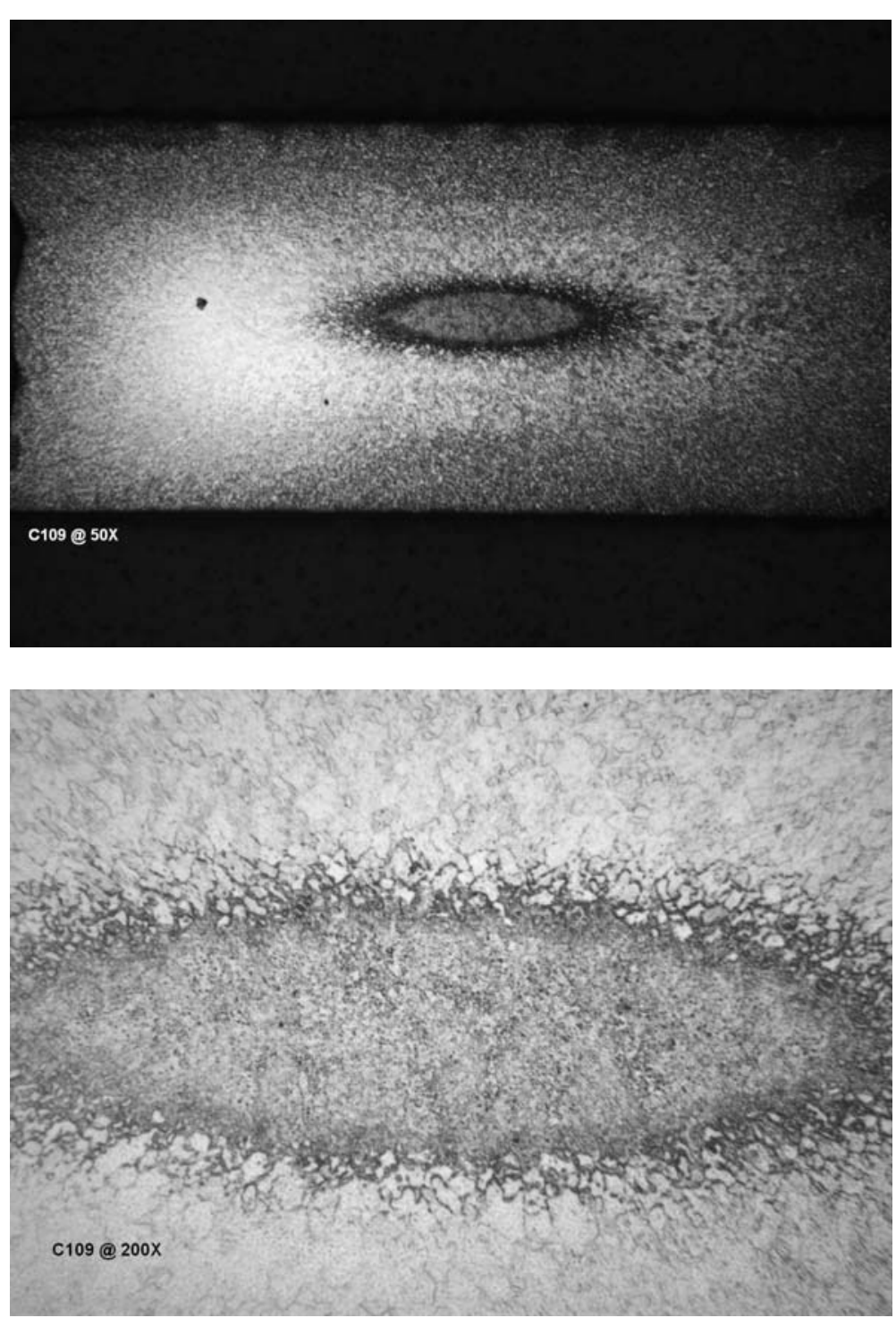

Page 29 of 33
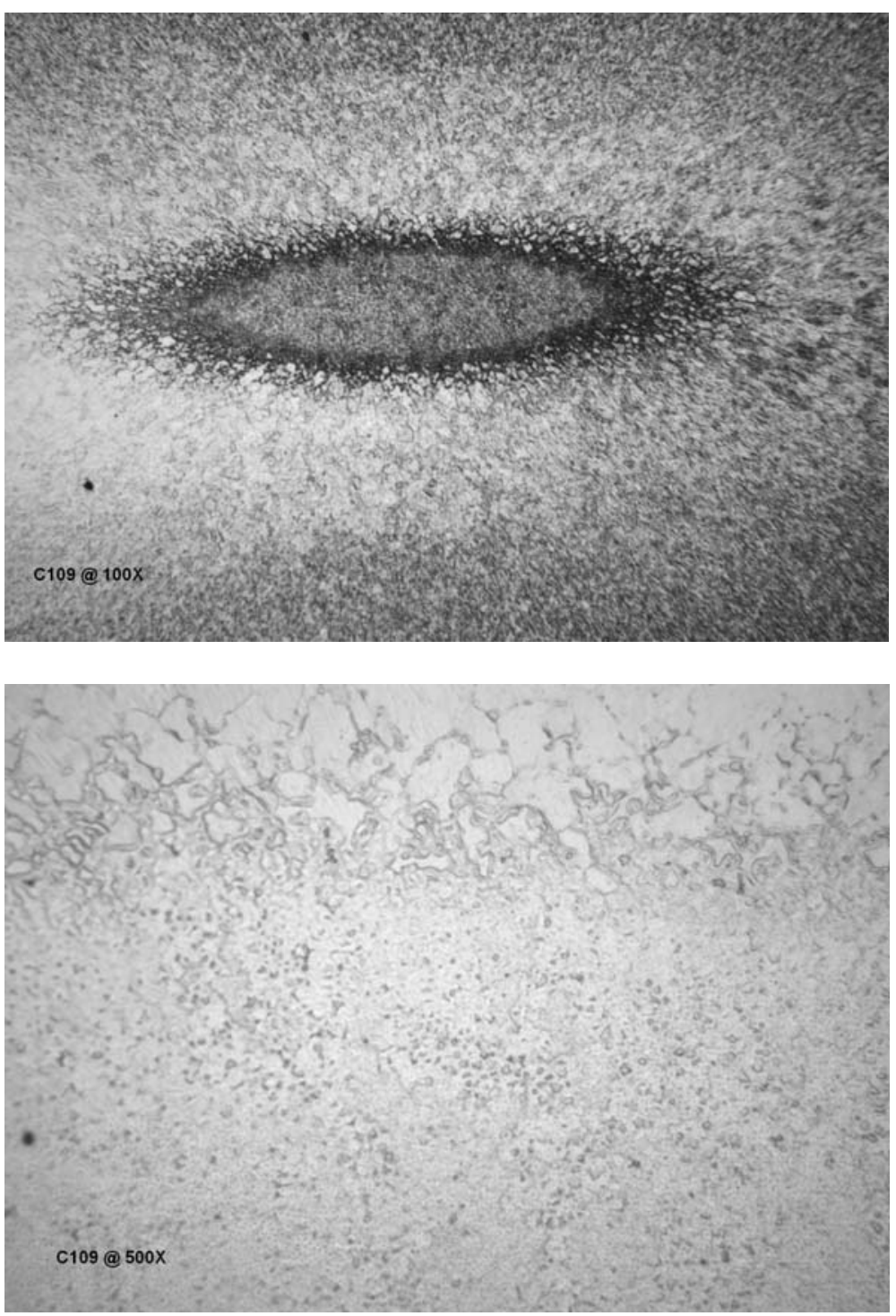

C109 High 
Appendix F. Micrographs of Type 304L stainless steel stems used for weld window verification.
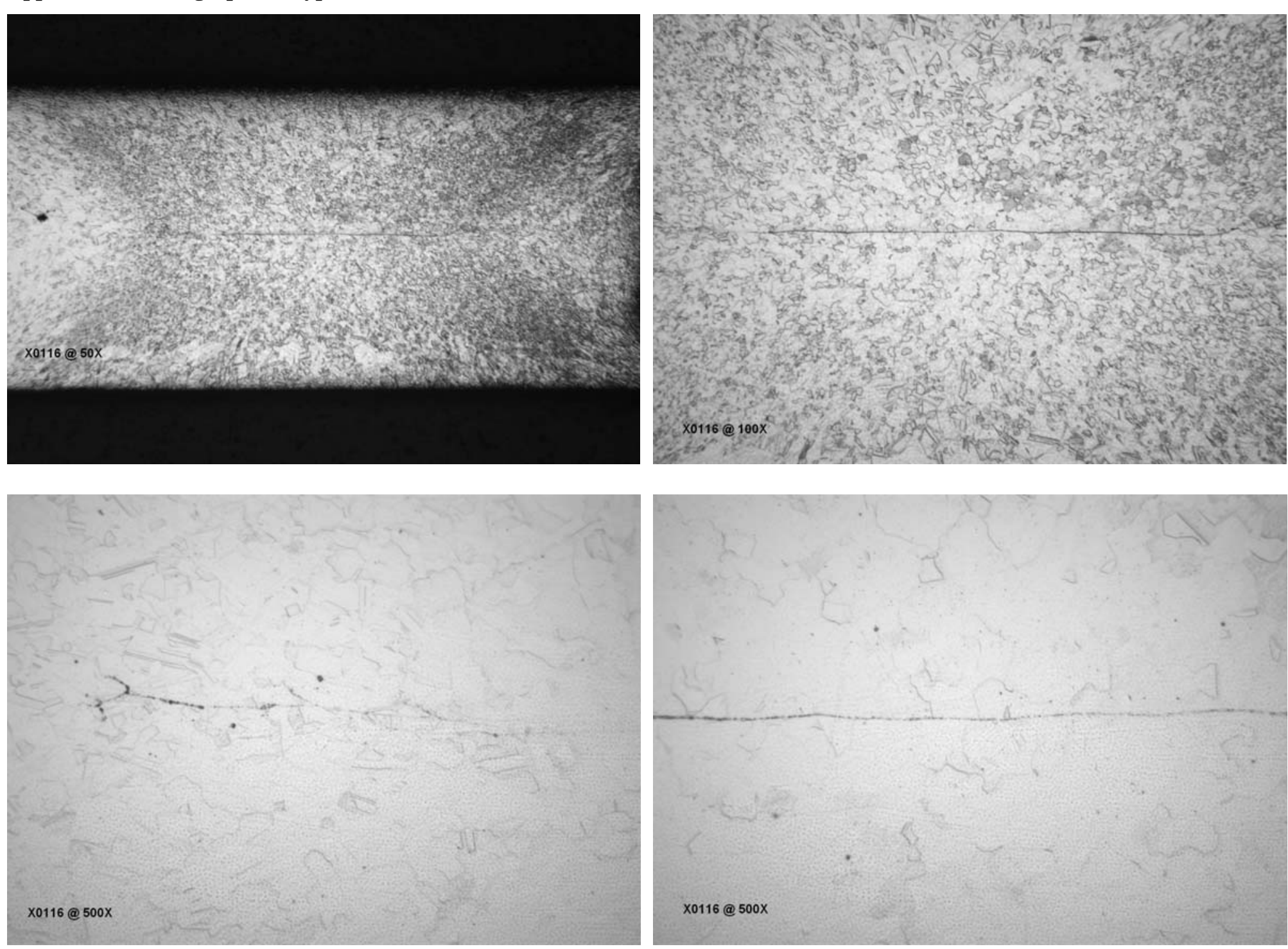

X0116 Low 

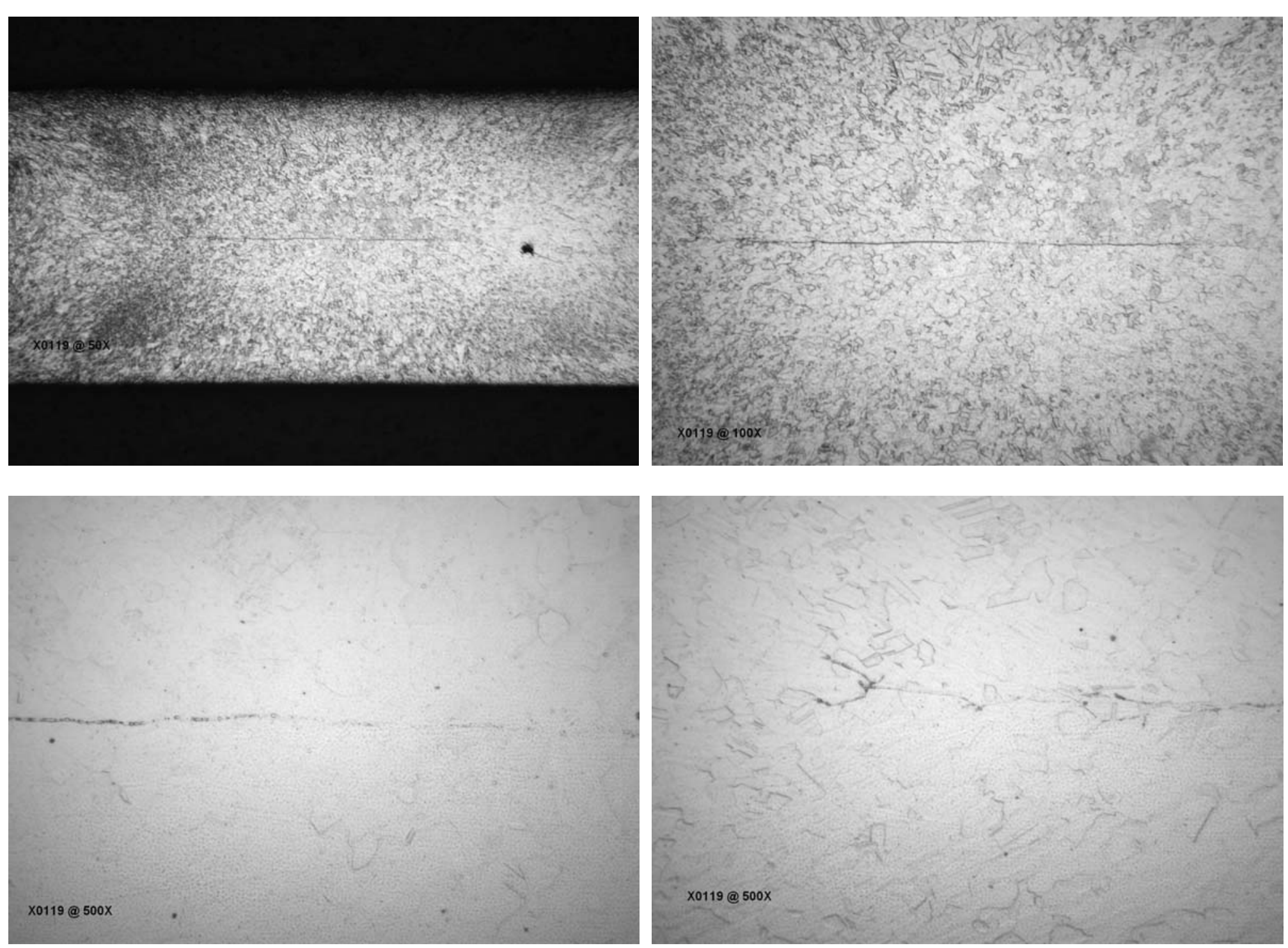

X0119 Low 

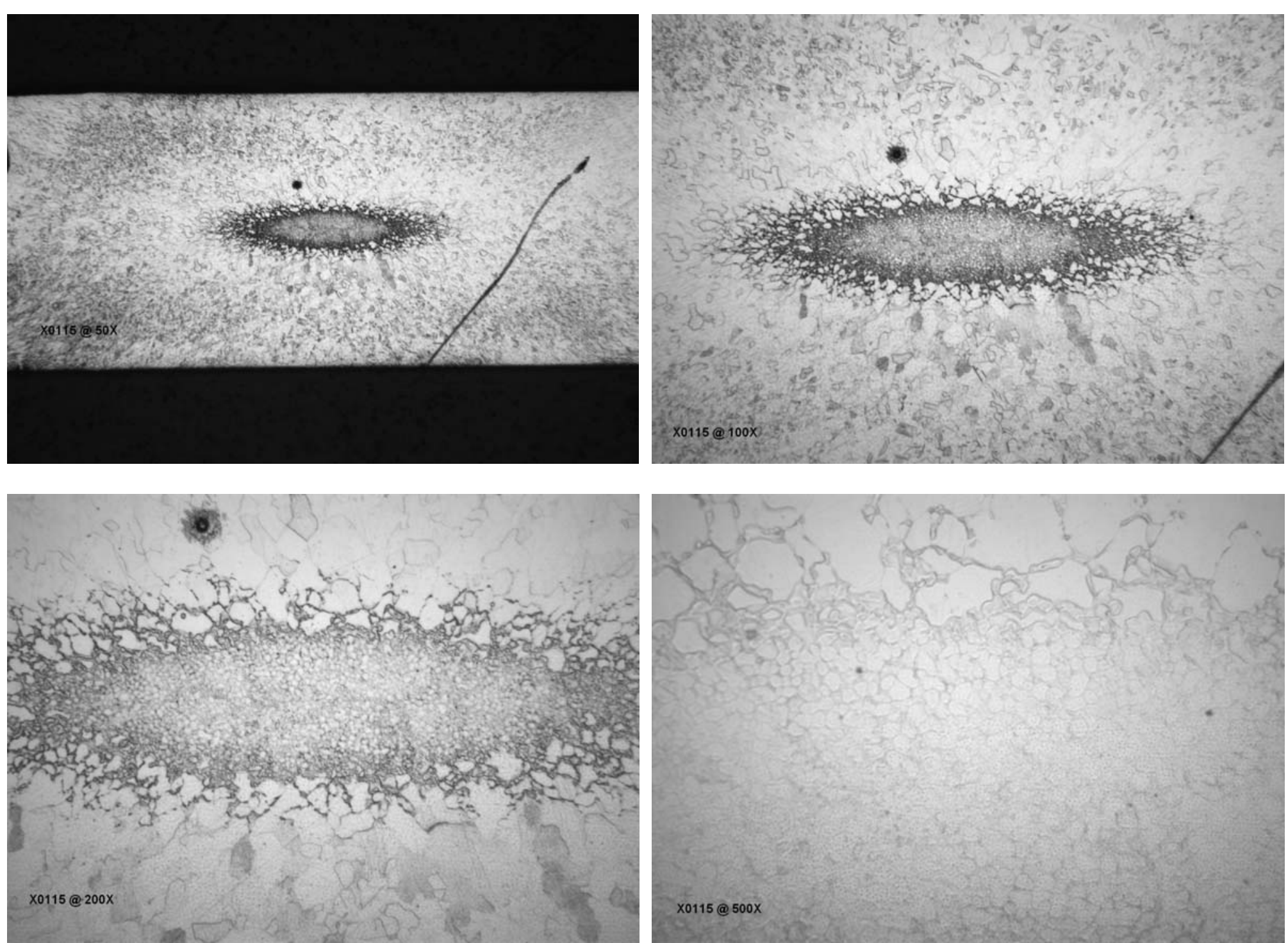

X0115 High 

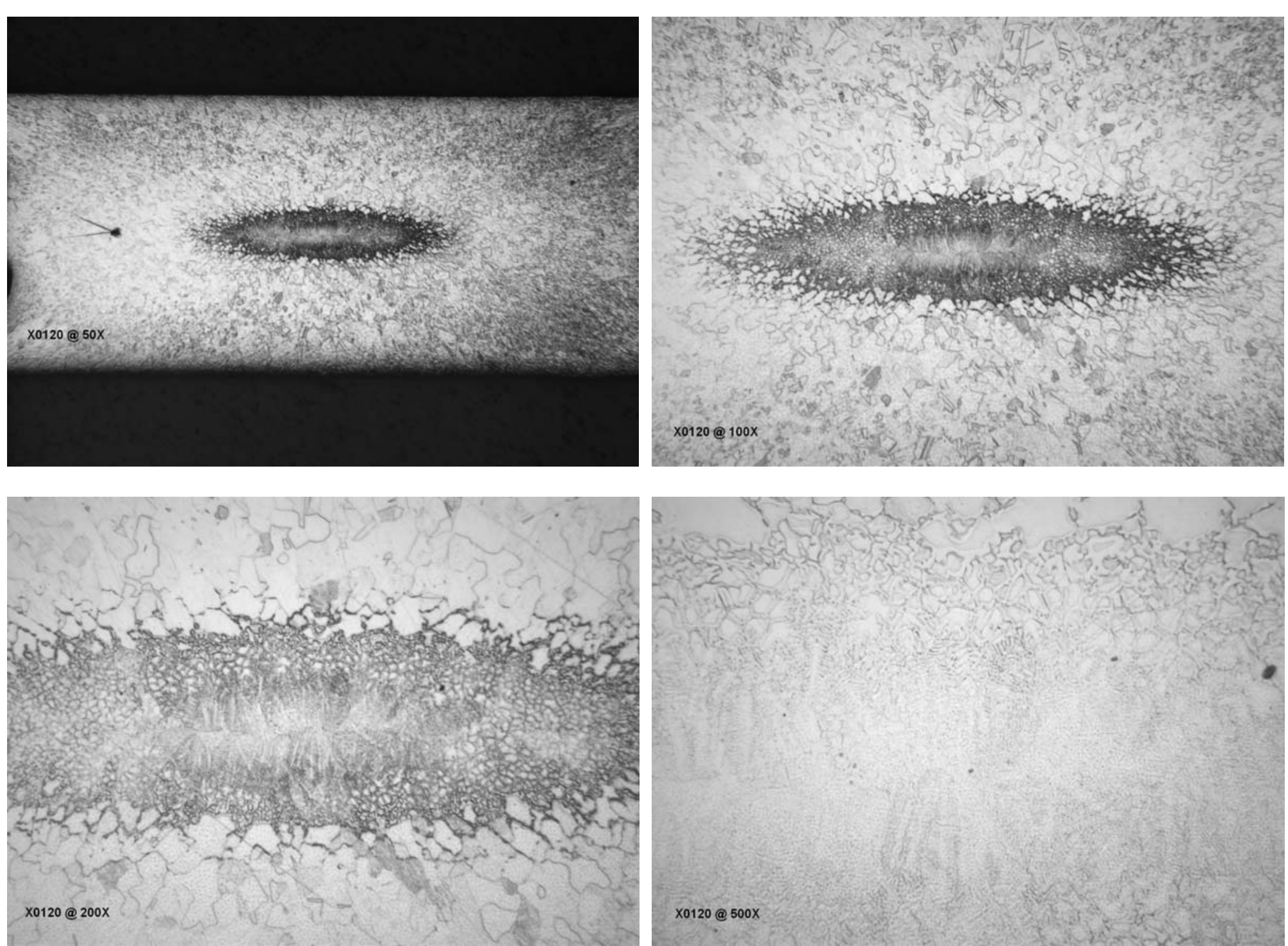

X0120 High 